\title{
Orchidaceae em afloramentos rochosos do estado de Pernambuco, Brasil
}

\author{
Orchidaceae from rocky outcrops of Pernambuco, Brazil
}

\author{
Edlley Pessoa ${ }^{1,2}$ \& Marccus Alves ${ }^{1}$
}

\begin{abstract}
Resumo
Em Pernambuco, além da Floresta Atlântica costeira, e dos Brejos de Altitude, as encostas orientais do Planalto da Borborema também são regiões ricas em espécies de Orchidaceae. Os afloramentos rochosos são comuns e têm sido indicados com uma das áreas mais representativas para a família no Nordeste do Brasil. O presente trabalho teve como objetivo inventariar a flora de orquídeas da área. Excursões foram realizadas entre 2005 e 2013, contemplando afloramentos rochosos de 13 áreas. Foram encontradas 29 spp. pertencentes a 18 gêneros, sendo Habenaria (seis spp.) e Epidendrum (quatro spp.) os mais representativos. Entre as espécies catalogadas destacam-se Acianthera prolifera e Octomeria alexandri como novos registros para Pernambuco, e Phragmipedium sargentianum que consta na lista de espécies ameaçadas de extinção no Brasil. As espécies são amplamente distribuídas a restritas na sua distribuição, dentre as quais, nove são endêmicas do Brasil. Este estudo corrobora informações anteriores sobre a elevada riqueza e abundância de Orchidaceae nas formações vegetais dos afloramentos rochosos, incluindo muitas espécies endêmicas. Apesar disto, poucas unidades de conservação no estado de Pernambuco englobam esse ecossistema tão importante.
\end{abstract}

Palavras-chave: Caatinga, ecossistemas montanhosos, flora, Floresta Atlântica, inselbergs.

\begin{abstract}
Besides the Atlantic Coastal Forest and the Brejos de Altitude in the state of Pernambuco, the eastern slopes of the Borborema plateau are also rich in species of Orchidaceae. Rocky outcrops are common and have been cited as one of the most representative sites for the family in Northeast Brazil. This study did a survey of the orchid flora on rocky outcrops in this state. Fieldwork was conducted from 2005 to 2013, and rocky outcrops from 13 different areas were visited. A total of 29 species and 18 genera were found. Habenaria (6 spp.) and Epidendrum (4 spp.) are the most representative genera. Of species recorded here, Acianthera prolifera and Octomeria alexandri are highlighted as new records for Pernambuco, and also Phragmipedium sargentianum which is on Brazil's endangered species list. The species are either widely distributed or have a restricted distribution; nine of these species are endemic to Brazil. This study confirms previous data on the great diversity and abundance of Orchidaceae in rocky habitats, including several endemic species. However, very few conservation units in Northeast Brazil contain this important ecosystem.
\end{abstract}

Key words: Caatinga, montane ecosystems, flora, Atlantic Forest, inselbergs.

\section{Introdução}

Orchidaceae é uma das maiores famílias de angiospermas, estando representada por 24.500 espécies (Dressler 2005), distribuídas em 800 gêneros (Dressler 1993), com centro de diversidade nos trópicos (Ramussen 1985). No Brasil ocorrem cerca de 2.500 espécies, sendo citadas para a Região Nordeste 598 espécies e 146 gêneros, e para o estado de Pernambuco 183 espécies e 77 gêneros (Barros et al. 2014).
Neste estado, além da Floresta Atlântica de Terras Baixas ao longo da costa e dos Brejos de Altitude interioranos, destacam-se as encostas orientais do Planalto da Borborema como regiões notavelmente ricas para família (Felix \& Carvalho 2002).

Nesses ambientes é comum a ocorrência de afloramentos rochosos que surgem em diferentes paisagens. Tais afloramentos formam ecossistemas isolados (Porembski \& Barthlott 2000), cuja vegetação difere marcadamente da região

\footnotetext{
${ }^{1}$ Universidade Federal de Pernambuco, CCB, Depto. Botânica, Lab. Morfo-Taxonomia Vegetal, Av. Prof. Moraes Rêgo s/n, 50670-901, Recife, PE, Brasil.

${ }^{2}$ Autor para correspondência: edlley_max@hotmail.com
} 
circundante (Porembski et al. 1998), apresentando características florísticas e fisionômicas determinadas principalmente por fatores abióticos, como intensa irradiação, altas temperaturas e baixa disponibilidade de nutrientes e água (Kluge \& Brulfert 2000).

A riqueza e importância dos afloramentos rochosos de Pernambuco são citadas por Martinelli (2007), que os classifica como áreas prioritárias para estudos de biodiversidade e criação de unidades de conservação.

Inventários florísticos recentes em afloramentos rochosos na Região Nordeste do Brasil citam Orchidaceae como uma das famílias mais representativas e de grande importância na formação das ilhas de vegetação (França et al. 2005, 2006; Gomes \& Alves 2009, 2010). Porembski et al. (1998) mostram que essas áreas tem altos níveis de endemismo, principalmente para a família Orchidaceae.

Como forma de contribuir para o conhecimento da flora desses ambientes, o presente trabalho busca inventariar as espécies da família em afloramentos rochosos no estado de Pernambuco em face da peculiaridade deste ambiente e para confirmar a reconhecida riqueza da família nestas áreas.

\section{Material e Métodos}

Os afloramentos rochosos graníticos em Pernambuco estão localizados principalmente no Planalto da Borborema, situado no extremo leste da região semi-árida brasileira. É uma das principais feições de relevo da porção oriental do sistema orográfico brasileiro (Moraes 1977) e é formado por um conjunto de maciços cristalinos que culminam entre 600 e $1000 \mathrm{~m}$ de altitude (Silva et al. 1993). Afloramentos rochosos areníticos podem ser encontrados na porção central do estado (clima semi-árido), especialmente no Parque Nacional do Catimbau, com formações pré-cambrianas recobertas por sedimentos paleo-mesozóicos da Bacia do Jatobá (Jacomine et al. 1973).

O clima da região é semi-árido, com estação chuvosa restrita a alguns meses do ano, a precipitação média anual varia entre 500 e $1.200 \mathrm{~mm}$ (Aw ou Bshw sensu Köppen) e as temperaturas variam entre $25-29^{\circ} \mathrm{C}$ (Silva et al. 1993). A vegetação ou matriz circundante pode ser de Caatinga ou Floresta Atlântica (brejos de altitude) (Ab'Sáber 2003; Andrade-Lima 1982), e esta exerce forte influência sobre a composição florística dos afloramentos (Burke 2002). Além dessa região, algumas áreas pontuais no litoral (ex. Cabo de Santo Agostinho) e na depressão sertaneja (ex. Triunfo) também possuem afloramentos graníticos.

Excursões de coleta foram realizadas entre 2005 e 2013, visando amostrar o maior número de afloramentos possível. As coletas foram seletivas e quando possível nos períodos secos e chuvosos. As expedições contemplaram um total de 13 afloramentos rochosos, localizados nos municípios de Agrestina, Belo Jardim, Bezerros, Bonito, Buíque, Camocim de São Félix, Jaqueira, Lagoa dos Gatos, São Caitano, Triunfo e Venturosa (Fig. 1, Tab. 1). Além destas áreas, amostras provenientes de outras localidades e depositadas nos herbários locais (HST, HVASF, IPA, PEUFR, UFP) foram devidamente analisadas.

Foram incluídas no inventário apenas as espécies detectadas em ilhas de vegetação sobre afloramentos rochosos. Aquelas observadas em áreas adjacentes à rocha, como a matriz circundante, foram coletadas, porém não incluídas neste trabalho. O material coletado foi herborizado seguindo metodologia usual (Mori et al. 1985). As flores foram fixadas e conservadas em álcool 70\% para descrição morfológica. As amostras foram depositadas no herbário Geraldo Mariz (UFP) com duplicatas enviadas para os herbários RB e NY (acrônimos segundo Thiers continuously updated).

Optou-se por apresentar apenas uma amostra por município. Todos os demais espécimes estão indicados na lista de exsicatas. Táxons infraespecíficos não foram considerados nesse estudo. A terminologia morfológica segue Harris \& Harris (2001) e Gonçalves \& Lorenzi (2007).

As espécies foram localmente classificadas como: 1. raras quando são conhecidas populações pequenas restritas a menos de três localidades, 2 . ocasionais quando possuem pequenas populações em diversas $(>3)$ localidades ou quando possuem grandes populações em poucas localidades, e 3. abundantes quando são observadas grandes populações em diversas áreas.

Dados sobre a distribuição geográfica foram obtidos a partir de literatura especializada (Barros et al. 2014; Govaerts et al. 2014). As ilustrações foram confeccionadas com base em exsicatas, amostras conservadas em meio líquido e fotos das espécies in vivo.

\section{Resultados e Discussão}

Foram encontradas 29 espécies pertencentes a 18 gêneros nos afloramentos rochosos estudados, 
Tabela 1 - Localidades visitadas com seus respectivos municípios, coordenadas geográficas e ecossistema da matriz circundante.

Table 1 - Visited localities with municipalities, geographic coordinates and ecosystem.

\begin{tabular}{|c|c|c|c|c|}
\hline Afloramento & Município & Coordenadas geográficas & Ecossistema (matriz) & No Gêneros/Espécies \\
\hline Parque Nacional do Catimbau & Buíque & $08^{\circ} 37^{\prime} 23^{\prime \prime} \mathrm{S}-37^{\circ} 09^{\prime} 21^{\prime \prime} \mathrm{W}$ & Caatinga & $4 / 4$ \\
\hline Pedra Antonio Bezerra & Bezerros & $08^{\circ} 20^{\prime} 09^{\prime \prime} \mathrm{S}-35^{\circ} 50^{\prime} 09^{\prime \prime} \mathrm{W}$ & Caatinga & $7 / 10$ \\
\hline Pedra Cabeça de Velho & Agrestina & $08^{\circ} 23^{\prime} 29^{\prime \prime} \mathrm{S}-36^{\circ} 00^{\prime} 37^{\prime \prime} \mathrm{W}$ & Floresta Atlântica & $3 / 5$ \\
\hline Pedra do Caboclo & Belo Jardim & $08^{\circ} 14^{\prime} 27^{\prime \prime} \mathrm{S}-36^{\circ} 23^{\prime} 06^{\prime \prime} \mathrm{W}$ & Caatinga & $6 / 7$ \\
\hline Pedra do Cachorro & São Caetano & $08^{\circ} 32^{\prime} 83^{\prime \prime} \mathrm{S}-36^{\circ} 14^{\prime} 28^{\prime \prime} \mathrm{W}$ & Caatinga & $8 / 11$ \\
\hline $\begin{array}{l}\text { Pedra do Cruzeiro } \\
\text { (Serra do Negra) }\end{array}$ & Bezerros & $08^{\circ} 39^{\prime} 25^{\prime \prime} \mathrm{S}-35^{\circ} 11^{\prime} 16^{\prime \prime} \mathrm{W}$ & Floresta Atlântica & $7 / 8$ \\
\hline $\begin{array}{l}\text { Pedra do Cruzeiro } \\
\text { (Serra do Urubu) }\end{array}$ & Jaqueira & $08^{\circ} 43^{\prime} 11^{\prime \prime} \mathrm{S}-35^{\circ} 50^{\prime} 38^{\prime \prime} \mathrm{W}$ & Floresta Atlântica & $8 / 9$ \\
\hline Pedra do Guariba & Agrestina & $08^{\circ} 22^{\prime} 55^{\prime \prime} \mathrm{S}-35^{\circ} 50^{\prime} 38^{\prime \prime} \mathrm{W}$ & Floresta Atlântica & $4 / 4$ \\
\hline Pedra do Mosquito & $\begin{array}{l}\text { Lagoa dos } \\
\text { Gatos }\end{array}$ & $08^{\circ} 42^{\prime} 30^{\prime \prime} \mathrm{S}-35^{\circ} .50^{\prime} 59^{\prime \prime} \mathrm{W}$ & Floresta Atlântica & $4 / 4$ \\
\hline Pedra do Rosário & Bonito & $08^{\circ} 29^{\prime} 48^{\prime \prime} \mathrm{S}-35^{\circ} 40^{\prime} 02^{\prime \prime} \mathrm{W}$ & Floresta Atlântica & $6 / 8$ \\
\hline Pedra Furada & Venturosa & $08^{\circ} 57^{\prime} 47^{\prime \prime} \mathrm{S}-36^{\circ} 87^{\prime} 42^{\prime \prime} \mathrm{W}$ & Caatinga & $0 / 0$ \\
\hline Pedra Náa Nazaré & $\begin{array}{l}\text { Camocim de } \\
\text { São Félix }\end{array}$ & $08^{\circ} 19^{\prime} 38^{\prime \prime} \mathrm{S}-35^{\circ} 45^{\prime} 12^{\prime \prime} \mathrm{W}$ & Caatinga & $6 / 7$ \\
\hline Pico do Papagaio & Triunfo & $07^{\circ} 49^{\prime} 53^{\prime \prime} \mathrm{S}-38^{\circ} 04^{\prime} 36^{\prime \prime} \mathrm{W}$ & Caatinga & $7 / 7$ \\
\hline
\end{tabular}

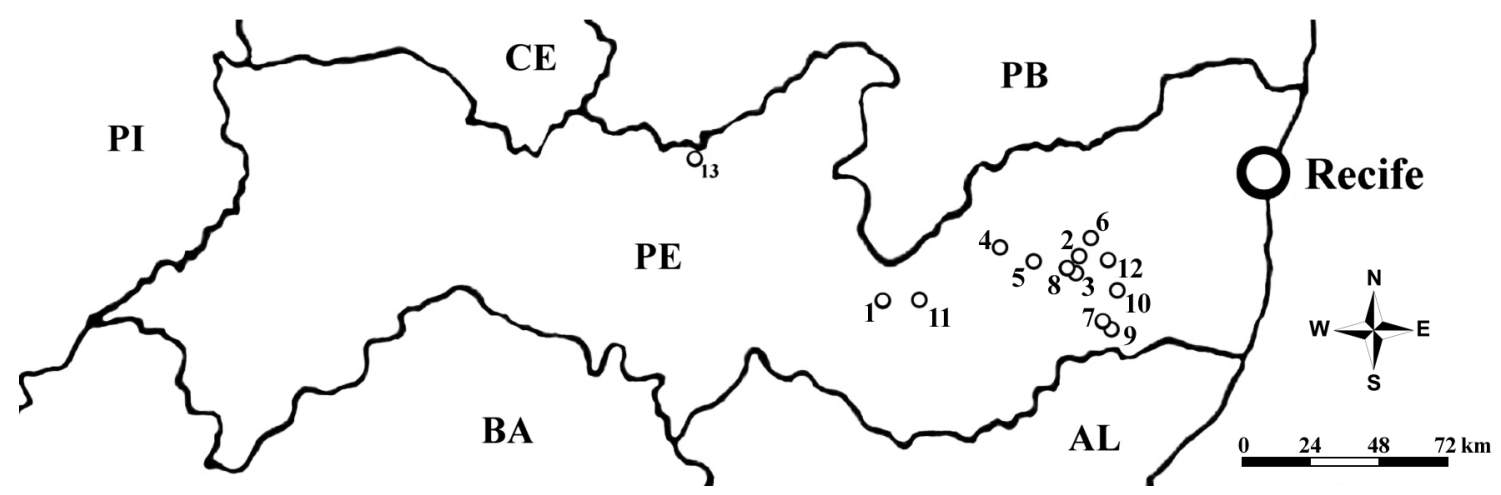

Figura 1 - Localidades visitadas. A. Mapa do Brasil; B. Mapa de Pernambuco: 1. Parque Nacional do Catimbau, 2. Pedra Antônio Bezerra, 3. Pedra Cabeça de Velho, 4. Pedra do Caboclo, 5. Pedra do Cachorro, 6. Pedra do Cruzeiro (Serra Negra), 7. Pedra do Cruzeiro (Serra do Urubu), 8. Pedra do Guariba, 9. Pedra do Mosquito, 10. Pedra do Rosário, 11. Pedra Furada, 12. Pedra Nª Sa Nazaré, 13. Pico do Papagaio.

Figure 1 - Visited localities. A. Brazillian map; B. Pernambuco's map: 1. Catimbau National Park, 2. Pedra Antônio Bezerra, 3. Pedra Cabeça de Velho, 4. Pedra do Caboclo, 5. Pedra do Cachorro, 6. Pedra do Cruzeiro (Serra Negra), 7. Pedra do Cruzeiro (Serra do Urubu), 8. Pedra do Guariba, 9. Pedra do Mosquito, 10. Pedra do Rosário, 11. Pedra Furada, 12. Pedra Nasa Nazaré, 13. Pico do Papagaio.

sendo Habenaria (seis spp.) e Epidendrum (quatro spp.), os gêneros mais representativos. Acianthera prolifera (Herb. ex Lindl.) Pridgeon \& M.W. Chase e Octomeria alexandri Schltr. são novos registros para o estado de Pernambuco, constituindo o extremo norte de distribuição dessas espécies. Phragmipedium sargentianum (Rolfe) Rolfe está citado entre as espécies ameaçadas de extinção no Brasil (MMA 2008; Menini Neto et al. 2013), tendo sido observadas duas pequenas populações em áreas com bom estado de conservação. 
A flora de orquídeas dos afloramentos rochosos de Pernambuco inclui espécies endêmicas do Brasil, como Acianthera ochreata (Lindl.) Pridgeon \& M.W.Chase, Brassavola tuberculata Hook. Cyrtopodium flavum (Nees) Link \& Otto ex Rchb., C. holstii L.C.Menezes, Epidendrum cinnabarinum Salzm. ex Lindl., E. flammeum E. Pessoa \& M. Alves, Octomeria alexandri Schltr., Prescottia plantaginifolia Lindl e Prosthechea alagoensis (Pabst) W.E. Higgins.

As espécies mais comuns entre os afloramentos rochosos (ocorrendo em mais da metade das áreas) são $A$. ochreata, C. flavum, E. cinnabarinum e $P$. plantaginifolia.

Os afloramentos rochosos que apresentaram maior riqueza de espécies foram a Pedra Antônio Bezerra, P. do Cachorro, P. do Cruzeiro (Bezerros), P. do Cruzeiro (Jaqueira) e a P. do Rosário. Estas são as áreas mais altas dentre aquelas visitadas, com altitudes variando de 850 a $1100 \mathrm{~m}$.
Por outro lado as áreas menos ricas em espécies foram a Pedra Furada e os afloramentos rochosos do Vale do Catimbau, ambos localizados na face ocidental do Planalto da Borborema, que é comprovadamente mais seco que a porção oriental (Ab’Sáber 1999).

As espécies encontradas nos afloramentos rochosos, em sua maioria, estão ausentes nas áreas circundantes, corroborando a importância da conservação desse ecossistema. Isso corrobora as indicações de Martinelli (2007), de que tais áreas funcionam como refúgios para espécies de ampla distribuição que não ocorrem atualmente em áreas de Caatinga s.s. ou Floresta Atlântica s.s., entretanto os afloramentos também apresentam algumas espécies endêmicas (Martinelli 2007).

No entanto, as unidades de conservação (UC) no estado que englobam esse ecossistema tão importante ecologicamente ainda são escassas.

\section{Chave para identificação das Orchidaceae dos afloramentos rochosos de Pernambuco}

1. Inflorescências laterais.

2. Pseudobulbos heteroblásticos; folhas apicais e basais.

3. Duas folhas apicais e 2-3 basais, elípticas, ovado-elípticas a oblongas .... Gomesa flexuosa

3'. Apenas uma folhas apical, cilíndricas ................................... Bulbophyllum aff. rupicolum

2'. Pseudobulbos homoblásticos; folhas distribuídas ao longo do caule.

4. Flores amarelo-ouro a amarelo-esverdeadas, margem do lobo mediano do labelo inteira ....

4'. Flores marrons rajadas de amarelo, margem do lobo mediano do labelo verrucosa Cyrtopodium flavum Cyrtopodium holstii

1'. Inflorescências terminais.

5. Flores calcaradas ou com mento.

6. Planta áfila durante a floração; flores róseas a avermelhadas Sacoila lanceolata

6'. Folhas presentes durante a floração; flores verdes, brancas ou amareladas.

7. Pétalas bipartidas, labelo tripartido, segmentos laterais desenvolvidos.

8. Cálcar $\leq 2,8 \mathrm{~cm}$ de compr.; ovário pedicelado $\leq 3,3 \mathrm{~cm}$ compr.

Habenaria pratensis

8. Cálcar $>6 \mathrm{~cm}$ compr.; ovário pedicelado $>6 \mathrm{~cm}$ de compr. ..... Habenaria trifida

7'. Pétalas e labelo inteiros ou quando partidos com segmentos laterais pouco desenvolvidos.

9. Pétalas estreito elíptico-falcadas, ápice agudo Habenaria hexaptera

9'. Pétalas oblongo-falcadas ou espatuladas, ápice obtuso ou truncado-sinuoso.

10. Ápice das pétalas truncado-sinuoso; cálcar $<3 \mathrm{~cm}$ compr.

Habenaria petalodes

10'. Ápice das pétalas obtuso; cálcar $>3 \mathrm{~cm}$ compr.

11. Raque exposta; cálcar $>5 \mathrm{~cm}$ compr., arqueado ..... Habenaria hamata

11'. Raque completamente coberta por brácteas; cálcar $<5 \mathrm{~cm}$ compr., não arqueado

Habenaria obtusa

5'. Flores não calcaradas e sem mento.

12. Caule unifoliado.

13. Caules intumescidos em pseudobulbos fusiformes e sobrepostos 
13'. Caules não intumescidos em pseudobulbos.

14. Flores com sépalas laterais livres.

15. Inflorescências em racemos; sépalas e pétalas $\geq 2,5 \mathrm{~cm}$ compr.

Brassavola tuberculata

15'. Inflorescências em fascículos; sépalas e pétalas $<2,5 \mathrm{~cm}$ compr.

Octomeria alexandri

14'. Flores com sépalas laterais conadas.

16. Folhas linear-lanceoladas a elípticas; flores laranjas a avermelhadas, margens das pétalas e labelo inteiras Acianthera ochreata

16'. Folhas ovadas; flores purpúreas, margens das pétalas e labelo minutamente serreadas ... Acianthera prolifera

12'. Caule bi a multifoliado.

17. Folhas em rosetas.

18. Pedúnculo da inflorescência $\geq 59 \mathrm{~cm}$ compr.; flores ressupinadas, sépalas externamente velutinas Phragmipedium sargentianum

18'. Pedúnculo da inflorescência $<59 \mathrm{~cm}$ compr.; flores não ressupinadas, sépalas glabras.

19. Folhas $\leq 4,5 \mathrm{~cm}$ compr.; flores alvas, labelo $\leq 11 \mathrm{~mm}$ compr., ápice arredondado

Prescottia oligantha

19'. Folhas $>6,5 \mathrm{~cm}$ compr.; flores esverdeadas, labelo $>2 \mathrm{~mm}$ compr., ápice agudo Prescottia plantaginifolia

17'. Folhas nunca em rosetas basais (ao longo ou no ápice do caule)

20. Caule intumescido em pseudobulbo.

21. Folhas ao longo do pseudobulbo; pseudobulbos $\leq 1,5 \mathrm{~cm}$ compr.

Polystachya estrellensis

21'. Folhas no ápice de pseudobulbo; pseudobulbos $>1,5 \mathrm{~cm}$ compr.

22. Pseudobulbos ovóides a obclavóides; folhas $\geq 40 \mathrm{~cm}$ compr.

Encyclia oncidioides

22'. Pseudobulbos fusiformes; folhas $\leq 21 \mathrm{~cm}$ compr.

23. Folhas $\leq 6 \mathrm{~cm}$; flores não ressupinadas, labelo inteiro

Prosthechea alagoensis

$23^{\prime}$. Folhas $>6 \mathrm{~cm}$; flores ressupinadas, labelo trilobado

Schomburgkia gloriosa

20'. Caule não intumescido em pseudobulbo.

24. Folhas plicadas; coluna completamente livre do labelo Sobralia liliastrum

24'. Folhas conduplicadas; coluna adnata ao labelo.

25. Folhas lanceoladas a ovadas; epicálice presente nas flores e persistente nos frutos ... Epistephium lucidum

25 '. Folhas oblongas a elípticas; epicálice ausente nas flores e frutos.

26. Raque $>$ pedúnculo; labelo inteiro Epidendrum rigidum

26 '. Raque $<$ pedúnculo; labelo trilobado.

27. Sépala dorsal $>1,7 \mathrm{~cm}$ compr., margem dos lobos laterais do labelo fortemente recortada ou franjada Epidendrum cinnabarinum

$27^{\prime}$. Sépala dorsal $\leq 1,2 \mathrm{~cm}$ compr., margem dos lobos laterais do labelo denticulada.

28. Flores lilases ou róseas, labelo com um único calo multifacetado ..... Epidendrum secundum

28'. Flores amarelas, laranjas ou vermelhas, labelo com dois calos carnosos arredondados na base e um calo disposto longitudinalmente, em forma de quilha Epidendrum flammeum 
1. Acianthera ochreata (Lindl.) Pridgeon \& M.W.Chase, Lindleyana 16: 245 2001. Fig. 2a Rupícolas. Ramicaule 2,5-5,5 cm compr., cilíndrico. Folha $1,6-10,5 \times 0,6-0,8 \mathrm{~cm}$, presente na floração, apical, conduplicada, linear-lanceolada a elíptica, crassa, ápice agudo. Inflorescência terminal, racemo, pedúnculo 2,5-3,5 cm compr.; raque 1,5-5,5 cm compr. Flores ressupinadas, laranjas a avermelhadas, não calcaradas, carnosas; sépala dorsal 3-5 × 1,2-2 mm, oblongo-elíptica, ápice agudo, sépalas laterais 3-6 × 1,2-2 mm, lanceoladas a ovadas, conadas, ápice agudo; pétalas 2,5-3 × $1 \mathrm{~mm}$, estreito-oblongas, ápice agudo a arredondado; labelo 2,5-2,7 × 1-1,5 mm, obovado a ligulado, obscuramente trilobado, ápice arredondado, margem inteira; coluna ca. $2 \mathrm{~mm}$ compr., polínias 4, inteiriças; ovário pedicelado 1-3 $\mathrm{mm}$ compr. Fruto 1-1,5 × 0,4 cm, elipsóide.

Material examinado selecionado: Agrestina, 7.IV.2007, fl., P. Gomes et al. 263 (RB, UFP). Belo Jardim, 11.I.2012, fr., E. Pessoa et al. 912 (UFP). Bezerros, 12.VI.2009, fl. e fr., E. Pessoa et al. 95 (NY, RB, UFP). Buíque, 27.IV.1995, fl., M. Luceño 322 (UFP). Camocim de São Félix, 9.I.2012, fr., E. Pessoa et al. 872 (UFP). São Caitano, 29.V.2010, fl., E. Pessoa \& K. Mendes 315 (RB, UFP). Triunfo, 12.I.2012, fl., E. Pessoa et al. 918 (RB, UFP).

Acianthera ochreata ocorre no Nordeste e Sudeste do Brasil (Barros et al. 2014). É uma das espécies mais abundantes na área, sendo observadas grandes populações, algumas vezes como principal componente das ilhas de vegetação. É facilmente distinguível da outra espécie do gênero por possuir folhas linear-lanceoladas a elípticas, e flores laranja a avermelhadas.

2. Acianthera prolifera (Herb. ex Lindl.) Pridgeon \& M.W.Chase, Lindleyana 16: 2452001.

Fig. 2b

Rupícolas. Ramicaule 3,5-7,5 cm compr., cilíndrico. Folha 1, 2,5-3,5 × 1,7-2 cm, presente na floração, apical, conduplicada, ovada, crassa, ápice agudo. Inflorescência terminal, racemo, pedúnculo 3-4 mm compr.; raque 4-6 $\mathrm{mm}$ compr. Flores ressupinadas, purpúreas, não calcaradas; sépala dorsal ca. $4 \times 2 \mathrm{~mm}$, ovado-elíptica, ápice agudo, sépalas laterais 4-4,5 × 2-2,5 mm, ovadolanceoladas, conadas, ápice agudo; pétalas $2-2,5$ $\times 1 \mathrm{~mm}$, elípticas, ápice agudo, minutamente serreadas; labelo 2-3 × 1,1 mm, ovado-ligulado, ápice arredondado, margem lateralmente serreada; coluna ca. $2 \mathrm{~mm}$ compr., polínias 4 , inteiriças; ovário pedicelado 1-2 mm compr. Fruto não observado.

Material examinado: São Caitano, 7.III.2010, fl., E. Pessoa \& K. Mendes 300 (UFP); 7.IX.1999, st., A. Liebig et al. 66 (PEUFR).

Acianthera prolifera ocorre no Nordeste e Sudeste do Brasil (Barros et al. 2014), sendo citada também para a Venezuela (Dunsterville \& Garay 1966). Representa um novo registro para Pernambuco, sendo rara neste estado que é o limite norte de sua distribuição na costa brasileira. A única população conhecida é composta por cerca de uma dezena de indivíduos a cerca de $1.000 \mathrm{~m}$ de altitude. Compõe um complexo taxonômico juntamente com Acianthera hamosa Barb. Rodr., A. limae Porto \& Brade e A. modestissima Rchb. f., e pode ser diferenciada destas espécies por um conjunto de caracteres morfológicos e morfométricos (Melo \& Borba 2011). Na área, se diferencia da outra espécie do gênero pelas folhas ovadas e flores purpúreas.

3. Brassavola tuberculata Hook., Bot. Mag. 56: t. 28781829.

Fig. 2c

Rupícolas. Caule 3-9,5 cm compr., cilíndrico. Folha 1, 9,5-17 × 0,2-0,4 cm, presente na floração, apical, conduplicada, cilíndrica, ápice agudo. Inflorescência terminal, racemo, pedúnculo $1-4 \mathrm{~cm}$ compr.; raque 2,2-8 cm compr. Flores ressupinadas, alvas, não calcaradas; sépala dorsal 2,5-3 × 0,5 $\mathrm{cm}$, estreito-elíptica, ápice agudo, sépalas laterais 2,5-3,6 × 0,35-0,5 cm, elíptico-lanceoladas, subfalcadas, ápice agudo; pétalas 2,5-3,5 ×0,3-0,4 $\mathrm{cm}$, estreito-elípticas, ápice agudo; labelo 2,2-3,2 $\times 1,7-2 \mathrm{~cm}$, obovado, ápice cuspidado, margem inteira; coluna 8-10 $\mathrm{mm}$ compr., polínias 8 , inteiriças; ovário pedicelado $6-7 \mathrm{~cm}$ compr. Fruto 9-10,2 × 0,8-1,2 cm, elipsóide.

Material examinado: Belo Jardim, 11.I.2012, fr., $E$. Pessoa et al. 910 (RB, UFP). Bezerros, 17.I.2010, fl., E. Pessoa \& M. Alves 250 (NY, RB, UFP). Camocim de São Félix, 9.I.2012, fr., E. Pessoa et al. 870 (NY, RB, UFP). São Caitano, 29.V.2010, st., E. Pessoa \& K. Mendes 318 (UFP).

Brassavola tuberculata é amplamente distribuída no Brasil (Barros et al. 2014), sendo ocasional na área de estudo e observada preferencialmente em encostas. Vegetativamente é confundida com Octomeria alexandri Schltr., a qual se diferencia por caracteres florais, como flores maiores dispostas em racemos. 

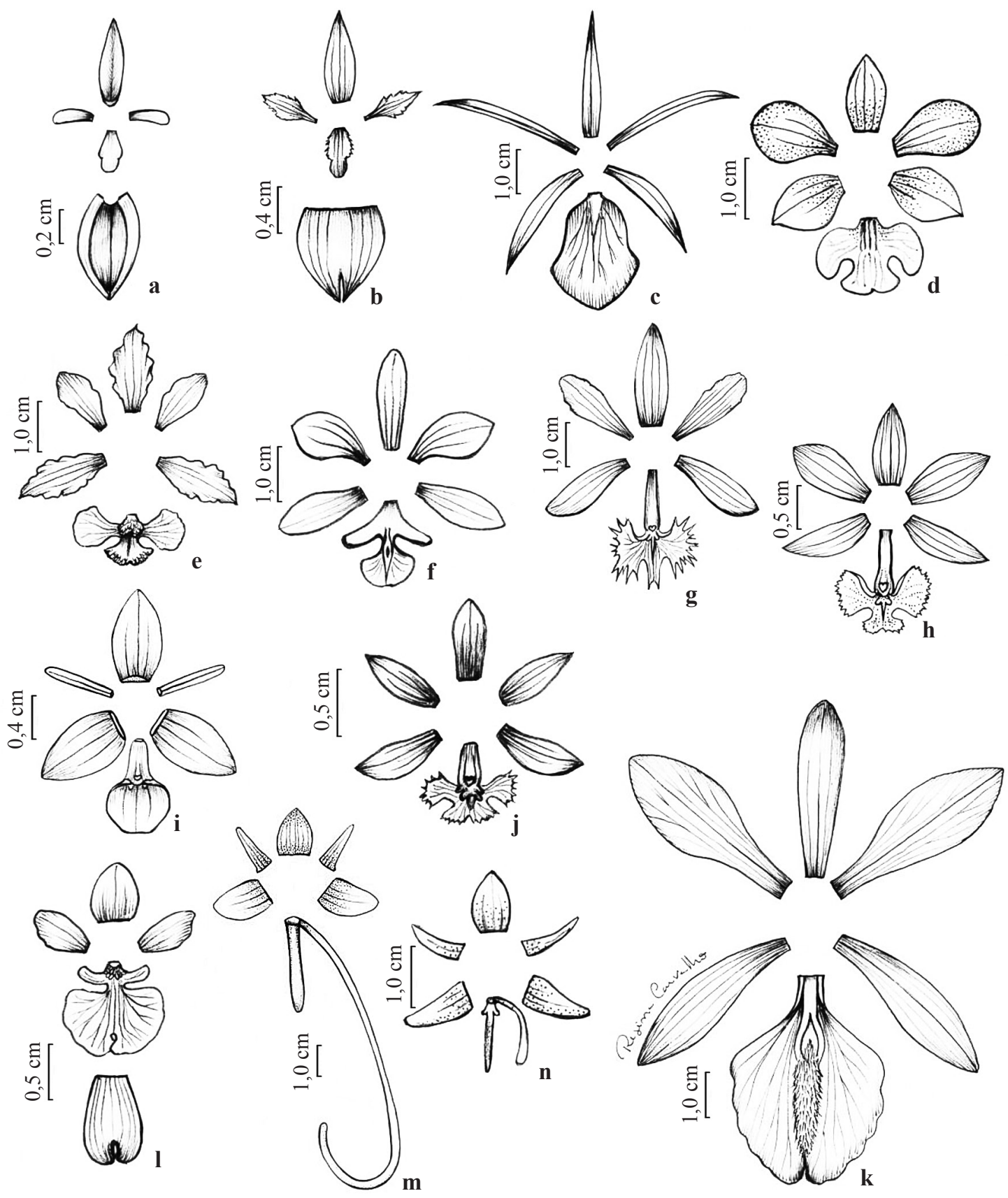

Figura 2 - Perianto - a. Acianthera ochreata; b. Acianthera prolifera; c. Brassavola tuberculata; d. Cyrtopodium flavum; e. Cyrtopodium holstii; f. Encyclia oncidioides; g. Epidendrum cinnabarinum; h. Epidendrum flammeum; i. Epidendrum rigidum; j. Epidendrum secundum; k. Epistephium lucidum; 1. Gomesa flexuosa; m. Habenaria hamata; n. Habenaria hexaptera.

Figure 2 - Dissected perianth - a. Acianthera ochreata; b. Acianthera prolifera; c. Brassavola tuberculata; d. Cyrtopodium flavum; e. Cyrtopodium holstii; f. Encyclia oncidioides; g. Epidendrum cinnabarinum; h. Epidendrum flammeum; i. Epidendrum rigidum; j. Epidendrum secundum; k. Epistephium lucidum; 1. Gomesa flexuosa; m. Habenaria hamata; n. Habenaria hexaptera. 
4. Bulbophyllum aff. rupicolum Barb. Rodr., Gen. Sp. Orch. 1: 39. 1877.

Rupícolas. Pseudobulbo 5-12 mm compr., cônico-anguloso, heteroblástico. Folha 1, $1,1-2,7 \times 0,15-0,2 \mathrm{~cm}$, presente na floração, apical, conduplicada, cilíndrica, ápice agudo. Inflorescência lateral, racemo; pedúnculo 2,5-3,5 cm compr.; raque 1-2,5 cm compr. Flores não observadas. Fruto não observado.

Material examinado: Triunfo, 12.I.2012, st., E. Pessoa et al. 921 (UFP).

Esta espécie é relacionada com representantes de Bulbophyllum com folhas cilíndricas pertencentes a $B$. sect. Micranthae Barb. Rodr., como B. adiamantinum Brade, B. epiphytum Barb. Rodr., B. insectiferum Barb. Rodr. e B. rupicola Barb. Rodr. Acredita-se estar mais relacionada à última espécie, porém tem menor porte, podendo ser inclusive uma nova espécie.

5. Cyrtopodium flavum (Nees) Link \& Otto ex Rchb., Iconogr. Bot. Exot. 3: $71830 . \quad$ Fig. 2d

Terrícolas ou rupícolas. Pseudobulbo 18-35 $\mathrm{cm}$ compr., fusiforme, homoblástico. Folhas $7-21,20-44 \times 2,3-3 \mathrm{~cm}$, presentes na floração, distribuídas ao longo do caule, convolutas, longoelípticas, ápice agudo. Inflorescência lateral, panícula; pedúnculo $65-110 \mathrm{~cm}$ compr.; raque 30-47 cm compr. Flores ressupinadas, amareloouro a amarelo-esverdeadas, não calcaradas; sépala dorsal $1,3-1,4 \times 0,8-0,9 \mathrm{~cm}$, ovadoelíptica, ápice agudo, sépalas laterais $1,2-1,4 \times$ $0,8-0,9 \mathrm{~cm}$, ovadas, ápice agudo; pétalas $1,4-1,5$ $\times 1-1,1 \mathrm{~cm}$, obovadas, ápice agudo; labelo 1,3-1,4 $\times 1,6-1,7 \mathrm{~cm}$, trilobado, lobos laterais $1-1,2 \times$ 0,6-0,7 cm, oblongos, inflexos, ápice redondo, lobo mediano 8-9 $\times 13 \mathrm{~mm}$, trapeziforme, ápice retuso, margem inteira, calos lamelares no disco; coluna 6-7 mm compr., polínias 4 , inteiriças; ovário pedicelado 1,5-1,8 cm compr. Fruto 4,5-6 $\times 2-3 \mathrm{~cm}$, elipsóide.

Material examinado selecionado: Bezerros, 17.I.2010, f1., E. Pessoa \& M. Alves 254 (UFP, RB). Bonito, 9.I.2012, fr., E. Pessoa et al. 885 (UFP). Camocim de São Félix, 9.I.2012, fr., E. Pessoa et al. 871 (UFP). Jaqueira, 10.III.2010, fr., E. Pessoa et al. 498 (UFP). Triunfo, 12.I.2012, fr., E. Pessoa et al. 920 (UFP).

Cyrtopodium flavum ocorre nas Regiões Nordeste, Sudeste e Sul do Brasil (Barros et al. 2014). É uma das espécies mais abundantes nos afloramentos da região, formando densas ilhas de vegetação. É tratado em algumas coleções como $C$. paranaense Schltr. e C. polyphyllum (Vell.) Pabst ex. F. Barros. Na área estudada pode ser diferenciada da outra espécie do gênero por possuir flores amareloouro com labelo de margens inteiras.

6. Cyrtopodium holstii L.C.Menezes, Schlechteriana 4: 149 1993. Fig 2e

Terrícolas ou rupícolas. Pseudobulbo 41-50 $\mathrm{cm}$ compr., fusiforme, homoblástico. Folhas $8-10,27-58 \times 4,5-6,6 \mathrm{~cm}$, presentes na floração, distribuídas ao longo do caule, convolutas, longoelípticas, ápice agudo. Inflorescência lateral, panícula; pedúnculo $102-110 \mathrm{~cm}$ compr.; raque 60-66 cm compr. Flores ressupinadas, marrons rajadas de amarelo, não calcaradas; sépala dorsal 1,8-2 × 0,9-1 cm, elíptica, ápice obtuso, sépalas laterais ca. 1,9 × 0,9-1 cm, elípticas, ápice agudo; pétalas $1,7-1,8 \times 1 \mathrm{~cm}$, obovadas, ápice redondo; labelo 1,4-2 × 2-2,1 cm, trilobado, lobos laterais $8-9 \times 8-9 \mathrm{~mm}$, orbiculares, inflexos, ápice redondo, lobo mediano 6-7 × 13-14 mm, flabelado, ápice retuso, margem verrucosa, calo verrucoso no disco; coluna ca. $8 \mathrm{~mm}$ compr., polínias 4 , inteiriças; ovário pedicelado 3,3-3,4 cm compr. Fruto $13,5-14 \times 2,5 \times 2,8 \mathrm{~cm}$, obovóide.

Material examinado: Buíque, 12.II.2008, fl., G.D. Alcântara 7 (HST). Caruaru, 17.II.2003, fl., K.A. Silva et al. 92 (PEUFR). Gravatá, 20.IV.2002, fl. e fr., S. M. Silva et al. 26 (UFP). São Caitano, 30.V.2010, fl., E. Pessoa \& K. Mendes 319 (UFP).

Cyrtopodium holstii ocorre nas Regiões Norte, Nordeste e Sudeste do Brasil (Barros et al. 2014). Rara na área de estudo, com poucos indivíduos observados em pequenas populações. Pode ser diferenciada da outra espécie do gênero na área estudada pelo maior porte e pelas flores amarelas rajadas de marrom com o lobo mediano do labelo com margem verrucosa.

7. Encyclia oncidioides (Lindl.) Schltr., Orchideen: 2101914.

Fig. $2 \mathrm{f}$

Rupícolas. Pseudobulbo 4-15 cm compr., ovóide a obclavóide, heteroblástico. Folhas 2-3, $40-51 \times 2,5-3 \mathrm{~cm}$, presentes na floração, apicais, conduplicadas, linear-lanceoladas, ápice agudo. Inflorescência terminal, panícula; pedúnculo 42-69 cm compr.; raque $28-35 \mathrm{~cm}$ compr. Flores ressupinadas, amarelo-acastanhadas, não calcaradas; sépala dorsal 1,3-1,7 × 0,6-0,8 cm, oblanceolada, ápice agudo, sépalas laterais 1,4-1,7 $\times 0,5-0,8 \mathrm{~cm}$, oblanceoladas, ápice agudo; pétalas 
$1,3-1,8 \times 0,8-1,2 \mathrm{~cm}$, obovadas a subunguiculadas, ápice mucronado; labelo 1,5-2 × 1,9-2,5 cm, trilobado, lobos laterais, 7-13 $\times 4-7 \mathrm{~mm}$, oblongos, ápice redondo, lobo mediano 8-19 × 9-13 mm, suborbicular, ápice retuso, margem inteira; calos lamelares no disco; coluna 9-13 mm compr.; polínias 4; ovário pedicelado $2-2,6 \mathrm{~cm}$ compr. Fruto 5-6 × 1,8-2 cm, elipsóide, muricado.

Material examinado: Belo Jardim, 11.I.2012, fl., E. Pessoa et al. 908 (RB, UFP). Bezerros, 17.I.2010, fl., E. Pessoa \& M. Alves 253 (UFP). Buíque, 26.I.2012, fl., C.R.S. Oliveira 172 (HVASF). São Caitano, 4.XII.2010, fl., E. Pessoa \& K. Mendes 411 (UFP). Triunfo, 12.I.2012, fl. e fr., E. Pessoa et al. 916 (NY, RB, UFP).

Encyclia oncidioides é amplamente distribuída no Brasil (Barros et al. 2014). Ocasional na área de estudo, podendo ocorrer em pequenas ou grandes populações. Distingue-se das demais espécies da área estudada pelos pseudobulbos ovóides a obclavóides, com 2 ou 3 folhas apicais e inflorescências em panículas.

8. Epidendrum cinnabarinum Salzm. ex Lindl., Gen. Sp. Orchid. P1.: 1061831 . Fig. 2g

Rupícolas ou terrícolas. Caule 13-21 cm compr., cilíndrico. Folhas 8-11, 4-7 cm $\times$ 1,5-2,3 cm, presentes na floração, distribuídas ao longo do caule, conduplicadas, oblongas, ápice obtuso. Inflorescência terminal, racemo; pedúnculo 40,5-50 cm compr.; raque $3,3-6 \mathrm{~cm}$ compr. Flores não ressupinadas, vermelho a vemelho-alaranjadas, não calcaradas; sépala dorsal 1,7-2,2 × 0,4-0,55 cm, oblongas, ápice agudo, sépalas laterais $1,7-2,3 \times 0,5-0,65 \mathrm{~cm}$, oblongas, falcadas, ápice agudo; pétalas 1,7-2,5 × 0,5-0,6 $\mathrm{cm}$, elípticas, ápice agudo; labelo $1-1,2 \times 1,5-1,7$ $\mathrm{cm}$, profundamente trilobado, lobos laterais $6-8$ $\times 10-13 \mathrm{~mm}$, margem fortemente recortada a franjada, lobo mediano 5-6×2-4,5 mm, deltóide, ápice emarginado, calo longitudinal no disco, e dois basais; coluna 1,4-1,7 cm compr., adnata ao labelo; polínias 4; ovário pedicelado 2,5-3,2 cm compr. Fruto não observado.

Material examinado selecionado: Belo Jardim, 11.I.2012, fl., E. Pessoa et al. 909 (UFP).Bezerros, 17.I.2010, fl., E. Pessoa \& M. Alves 247 (RB, UFP). Bonito, 10.I.2012, fl., E. Pessoa et al. 894 (RB, UFP). Camocim de São Félix, 9.I.2012, fl., E. Pessoa et al. 875 (RB, UFP). Jaqueira, 10.III.2010, fl., E. Pessoa et al. 505 (NY, RB, UFP).

Epidendrum cinnabarinum é endêmica da Região Nordeste do Brasil (Barros et al. 2014). Espécie muito abundante na área, algumas vezes compondo ilhas de vegetação monoespecíficas. Entre as espécies de Epidendrum dos afloramentos rochosos estudados é a que apresenta as maiores flores e pode ser diferenciado pela margem dos lobos laterais do labelo que é fortemente recortada a franjada.

\section{Epidendrum flammeum E.Pessoa \& M.Alves,} Taxon 61: 721. 2012.

Fig. $2 \mathrm{~h}$

Rupícolas ou terrícolas. Caule 10,5-73 cm compr., cilíndrico. Folhas 5-11, 3-9 × 0,8-3 cm, presentes na floração, distribuídas ao longo do caule, conduplicadas, oblongas a elípticas, ápice obtuso. Inflorescência terminal, racemo; pedúnculo 14-77 cm compr.; raque 3-4 cm compr. Flores não ressupinadas, amarelas, laranjas ou vermelhas, não calcaradas; sépala dorsal 7-12 × 3,2-5,5 mm, oblongo-ovadas, ápice agudo, sépalas laterais 7-14 × 3,9-6 mm, obovado-falcadas, ápice agudo; pétalas 8-13 × 3-5,9 mm, elípticas a ovadas, ápice agudo; labelo 3-6,7 × 9-16 mm, trilobado, lobos laterais $3,5-7 \times 4-7,5 \mathrm{~mm}$, margem denticulada, lobo mediano 2,2-3,8 × 3-6,8 mm, ápice bifurcado, calos 3,2 na base, carnosos arredondados, 1 longitudinal, em forma de quilha; coluna 5-11 mm compr., adnata ao labelo; polínias 4; ovário pedicelado 1,2-2,9 cm compr. Fruto 5-5,2 $\times$ 1,3-1,9 cm, globoso a elipsóide.

Material selecionado: Bonito, 20.VI.1995, fl., M. Alves \& al. 34545 (UFP). Brejo da Madre de Deus, 19.IV.1959, fl., D. Andrade-Lima 59-3354 (IPA). São Caitano, 7.III.2010, fl. e fr., E. Pessoa \& K. Mendes 306 (UFP).

Epidendrum flammeum é endêmica dos afloramentos rochosos da Região Nordeste (Pessoa et al. 2012). Esta espécie foi tratada como $E$. fulgens Brongn. por Gomes-Ferreira (1990) e Felix \& Carvalho (2002), devido principalmente a coloração alaranjada de suas flores. Dados moleculares e morfométricos demonstram estar mais relacionada à E. denticulatum Barb. Rodr. (Pessoa et al. 2012). Pode ser diferenciada das demais espécies de Epidendrum na área por possuir flores que variam desde o vermelho ao amarelo e pelas calosidades no labelo, que são formadas por um par de calos arredondados na base e um calo longitudinal que vai até o ápice em forma de quilha.

10. Epidendrum rigidum Jacq., Enum. Syst. Pl. 29. $1760 . \quad$ Fig. $2 \mathrm{i}$

Rupícolas. Caule 3,7-15 cm compr, cilíndrico. Folhas 5-10, 2,4-6 × 0,8-1,4 cm, 
presentes da floração, distribuídas ao longo do caule, conduplicadas, oblongas a elípticas, ápice arredondado. Inflorescência terminal, racemo; pedúnculo 5-13 mm compr.; raque 4-8 cm compr. Flores não ressupinadas, verdes, não calcaradas; sépala dorsal ca. $5 \times 2 \mathrm{~mm}$, lanceolada, ápice agudo, sépalas laterais 5-6 × 2-3 mm, lanceoladas, ápice agudo; pétalas $4-5 \times 1 \mathrm{~mm}$, linear, ápice agudo; labelo ca. $5 \times 3-3,5 \mathrm{~mm}$, suborbicular, ápice arredondado, margem inteira, calos 2 , na base, redondos; coluna 2,5-3 mm compr., inteiramente adnata ao labelo; polínias 4; ovário pedicelado 8-9 mm compr. Fruto 15-25 × 3-10 mm, ovóide.

Material examinado: Jaqueira, 21.IX.2011, fl. e fr., B.S. Amorim 1127 (UFP). Agrestina, 15.VII.2007, fl. e fr., $P$. Gomes 417 (UFP).

Epidendrum rigidum é amplamente distribuída na Região Neotropical (Govaerts et al. 2014) inclusive no Brasil (Barros et al. 2014). Rara nos afloramentos, sendo abundante nas áreas de Floresta Atlântica circundante. Na área pode ser facilmente diferenciada das demais espécies de Epidendrum por possuir pedúnculo curto (5-13 mm compr.).

11. Epidendrum secundum Jacq., Enum. Syst. Pl. $291760 . \quad$ Fig. $2 \mathrm{j}$

Rupícolas ou terrícolas. Caule 7-17 cm compr., cilíndrico. Folhas 5-9, 3-6,5 cm × 1,2-1,4 $\mathrm{cm}$, presentes na floração, distribuídas ao longo do caule, conduplicadas, oblongas a elípticas, ápice agudo, obtuso ou emarginado. Inflorescência terminal, racemo; pedúnculo $24-50 \mathrm{~cm}$ compr.; raque $2,5-6 \mathrm{~cm}$ compr. Flores não ressupinadas, lilases ou róseas, não calcaradas; sépala dorsal 6-8 $\times 2,5-3 \mathrm{~mm}$, oblongas, ápice agudo, sépalas laterais 7-9 $\times 3-4 \mathrm{~mm}$, oblanceoladas, ápice agudo; pétalas $7-8 \times 2-3 \mathrm{~mm}$, elípticas a oblanceoladas, ápice agudo; labelo 4-4,5 × 6-8 $\mathrm{mm}$, profundamente trilobado, lobos laterais, $2-3 \times 2-4 \mathrm{~mm}$, orbiculares, margem denticulada, lobo mediano $2-3 \times 2-4,5$ $\mathrm{mm}$, bilobado ou inteiro, margem denticulada, calo recortado de diversas formas no disco, coluna 3,5-4 $\mathrm{mm}$ compr., adnata ao labelo; polínias 4 ; ovário pedicelado $1-1,6 \mathrm{~cm}$ compr. Fruto $2,7-3,1 \times 1,6$ $\mathrm{cm}$, ovóide a elipsóide.

Material examinado selecionado: Belo Jardim, 11.I.2012. fl., E. Pessoa et al. 903 (UFP). Bezerros, 4.VI.2011, fl., E. Pessoa et al. 610 (NY, RB, UFP). Bonito, 10.I.2012, fl. e fr., E. Pessoa et al. 895 (NY, RB, UFP). Camocim de São Félix, 9.I.2012, fl., E. Pessoa et al. 874 (RB, UFP).
Epidendrum secundum é amplamente distribuída na Região Neotropical (Govaerts et al. 2014) inclusive no Brasil (Barros et al. 2014). Abundante na área de estudo, sendo visualmente em alguns afloramentos rochosos a espéciemais comum. Diferencia-se das demais espécies do gênero por possuir flores menores e de coloração lilás a rósea.

12. Epistephium lucidum Cogn., in Mart., Fl. bras. 3(4): 1411893.

Fig. $2 \mathrm{k}$

Terrícolas. Caule 74-104 cm compr., cilíndrico. Folhas 10-12, 5-11,5 × 2,7-7 cm, presentes na floração, distribuídas ao longo do caule, conduplicadas, lanceoladas a ovadas, ápice agudo. Inflorescência terminal, racemo; pedúnculo 14-17,5 cm compr.; raque 16,5-24,5 cm compr. Flores ressupinadas, róseas ou roxas, não calcaradas; epicálice presente, sépala dorsal 3,5-4,3 $\times 0,8-1,1 \mathrm{~cm}$, oblanceoladas, ápice agudo, sépalas laterais $3,8-4,3 \times 0,7-1,1 \mathrm{~cm}$, oblanceoladas, ápice agudo; pétalas 3,7-5 × 1,2-2 cm, obovadas, ápice obtuso; labelo $3,2-5,2 \times 1,6-3,4 \mathrm{~cm}$, obovado, ápice bilobado, margem ondulada, calos lamelares do centro a base; coluna $2,5-3 \mathrm{~cm}$ compr., adnata lateralmente ao labelo; polínias 4; ovário pedicelado $2,5-5 \mathrm{~cm}$ compr. Fruto $4-6 \times$ $0,8-1,1 \mathrm{~cm}$, fusiforme.

Material examinado: Bonito, 10.I.2012, fl. e fr., E. Pessoa et al. 898 (NY, RB, UFP); 21.IV.1994, fl., A. M. Miranda et al. 1674 (HST); 9.X.1997, fl., C. Ferreira (IPA).

Epistephium lucidum é amplamente distribuída na América do Sul (Govaerts et al. 2014), inclusive no Brasil (Barros et al. 2014). Rara na área e conhecida apenas para um afloramento rochoso onde existe uma pequena população. É facilmente diferenciada das outras espécies da área por possuir flores com epicálice.

13. Gomesa flexuosa (Lodd.) M.W.Chase \& N.H.Williams, Ann. Bot. (Oxford) 104: 396. 2009

Fig. 21

Rupícolas. Pseudobulbo 2,5-6 cm compr., elipsóide a ovóide, heteroblástico. Folhas 4-5, $2-10,5 \times 0,9-3,5 \mathrm{~cm}$, presentes na floração, 2 apicais e $2-3$ basais, conduplicadas, elípticas, ovado-elípticas a oblongas, ápice delicadamente mucronado. Inflorescência lateral, racemo ou panícula; pedúnculo 17-42 cm compr.; raque 4-11 $\mathrm{cm}$ compr. Flores ressupinadas, amarelas com maculas marrons avermelhadas, não calcaradas; sépala dorsal 6-7 ×4 mm, ovado-elíptica, ápice 
obtuso, sépalas laterais 8-9 × 5-6 mm, conadas até o terceiro quarto, côncavas, oblanceoladas, ápice agudo; pétalas 6,5-8 ×4-6 $\mathrm{mm}$, obovadas a suborbiculares, ápice arredondado; labelo 1,4-2 $\times$ 1,4-2,2 cm, trilobado, lobos laterais, 3-5 × 1,5-3 $\mathrm{cm}$, oblongos a deltóides, ápice redondo, lobo mediano 1-2,2 × 1,3-1,4 cm, suborbicular, ápice emarginado, margem ondulada, calo 1 , na base, recordado de varias formas; coluna $4-5 \mathrm{~mm}$ compr.; polínias 2; ovário pedicelado $1,5-2 \mathrm{~cm}$ compr. Fruto 2-4,5 × 1-1,2 cm, elipsóide.

Material examinado selecionado: Belo Jardim, 11.I.2012, fl., E. Pessoa et al. 905 (UFP).Bezerros, 18.XI.2005, st., P. Gomes et al. 169 (UFP). Caruaru, 14.IX.2009, fl., M. Sobral-Leite et al. 1077 (UFP). São Caitano, 7.III.2010, fl. e fr., E. Pessoa \& K. Mendes 304 (NY, RB, UFP).

Gomesa flexuosa é amplamente distribuída no Brasil (Barros et al. 2014), com ocorrência também para a Argentina (Govaerts et al. 2014). Análises moleculares recentes sugeriram a transferência de grande parte das espécies brasileiras de Oncidium Sw. para Gomesa R. Br. (Chase et al. 2009), posição também adotada no presente estudo. Ocasional na área de estudo, e observada formando grandes populações. Pode ser diferenciada das demais espécies da área pelos pseudobulbos elipsóides a ovóides, inflorescências laterais e flores amarelas com máculas marrons.

14. Habenaria hamata Barb. Rodr., Gen. Sp. Orchd. 1: 162. 1877.

Fig. $2 \mathrm{~m}$

Terrícolas. Caule 23-28 cm compr., cilíndricos. Folhas 5-12, 9,2-16,3 × 2,7-3,8 $\mathrm{cm}$, presentes na floração, distribuídas ao longo do caule, convolutas, lanceoladas a oblongolanceoladas, ápice agudo. Inflorescência terminal, racemo; pedúnculo $8,5-10,5 \mathrm{~cm}$ compr., raque 4-5,5 cm compr. Flores ressupinadas, brancas, calcaradas, cálcar 8,5-12 cm compr., arqueado; sépala dorsal 1,3-1,5 × 1-1,5 cm, ovada, ápice agudo, sépalas laterais 1,5-1,9 × 0,9-1 cm, oblongas a oblanceoladas, ápice agudo; pétalas $1,3-1,5 \times 0,4-0,5 \mathrm{~cm}$, oblongo-falcadas, ápice obtuso, inteiras; labelo 2,4-3 ×0,3-0,5 cm, estreitooblongo a linear, ápice obtuso, inteiro, margem inteira; coluna 8-10 mm compr.; polínias 2; ovário pedicelado 3-4,5 cm compr. Fruto não observado. Material examinado: Triunfo, 21.VII.1995, fl., L.P. Félix et al. 7189 (PEUFR); 8.VI.1997, fl., A.M. Miranda 2717 (HST, UFP).

Habenaria hamata ocorre na Guiana Francesa (Govaerts et al. 2014) e em todas as regiões do
Brasil (Barros et al. 2014). Rara na área de estudo, sendo observada após o período chuvoso. Pode ser diferenciada das demais espécies do gênero pelas sépalas mais longas $(\leq 1,5 \mathrm{~cm})$, e pelo cálcar arqueado.

15. Habenaria hexaptera Lindl., Gen. Sp. Orchid. P1. 316. 1835.

Fig. 2n

Terrícolas. Caule $23-28 \mathrm{~cm}$ compr., cilíndrico. Folhas 5-6, 4,4-8,5 × 0,8-1,7 cm, presentes na floração, distribuídas ao longo do caule, convolutas, lanceoladas, ápice agudo. Inflorescência terminal, racemo; pedúnculo $3,5-5,5 \mathrm{~cm}$ compr., raque $15-16,5 \mathrm{~cm}$ compr. Flores ressupinadas, calcaradas, cálcar 1,1-1,4 cm compr., verde-amareladas; sépala dorsal 7-9 $\times$ 5-6 $\mathrm{mm}$, ovada, ápice agudo, sépalas laterais 7-11× 3-4 mm, lanceoladas, ápice agudo; pétalas 6-9 $\times$ 1,5-2 mm, estreito elíptico-falcadas, ápice agudo, inteiras; labelo tripartido, segmentos laterais ca. $1 \mathrm{~mm}$ compr., lineares, ápice agudo, segmento mediano 8-9 × 1,5-2 mm, estreito-oblongo, ápice agudo, margem inteira; coluna 2,5-3 mm compr.; polínias 2; ovário pedicelado $1,3-1,8 \mathrm{~cm}$ compr. Fruto não observado.

Material examinado: Caruaru, 24.VII.2009, fl., $M$. Sobral-Leite et al. 915 (RB, UFP). Catende, 25.VI.2008, fl., M. Sobral-Leite et al. 812 (UFP).

Habenaria hexaptera ocorre na Bolívia, Colômbia, Peru, Venezuela (Batista et al. 2008), sendo também amplamente distribuída no Brasil (Barros et al. 2014). Rara na área e floresce logo após as chuvas. Pode ser diferenciada das demais espécies do gênero por possuir os segmento anterior das pétalas e laterais do labelo diminutos.

16. Habenaria obtusa Lindl., Gen. Sp. Orchid. Pl.: 315. 1835.

Fig. 3a

Terrícolas. Caule 20-32 cm compr., cilíndrico. Folhas 5-9, 5-12 × 1,5-2,3 cm, presentes na floração, distribuídas ao longo do caule, convolutas, linear-lanceoladas, ápice agudo. Inflorescência terminal, racemo; pedúnculo $6-9 \mathrm{~cm}$ compr.; raque 9,5-18 cm compr., completamente coberta por brácteas. Flores ressupinadas, calcaradas, cálcar 3,4-4,5 cm compr, alvo-esverdeadas; sépala dorsal 7-9 $\times 7 \mathrm{~mm}$, ovadas, ápice obtuso, sépalas laterais $10-12 \times 5 \mathrm{~mm}$, elíptico-falcadas, ápice agudo; pétalas 6-9 × 1,5-2,5 cm, oblongo-falcadas, ápice obtuso, segmento anterior inconspícuo; labelo 11-13 × 2-3 mm, estreito-oblongo, ápice arredondado, inteiro, margem inteira; coluna 
3-4,5 mm compr.; polínias 2; ovário pedicelado $1,8-2,3 \mathrm{~cm}$ compr. Fruto $1,8-2 \times 0,5 \mathrm{~cm}$, fusiforme. Material examinado: Bezerros, 4.VI.2011, fl. e fr., $E$. Pessoa et al. 609 (UFP). Caruaru, 14.IX.2009, fl., M. Sobral-Leite et al. 1070 (UFP). São Caitano, 30.V.2010, fl., E. Pessoa \& K. Mendes 320 (RB, UFP).

Habenaria obtusa ocorre na Venezuela, Colômbia, Equador, Guiana, Paraguai, Peru, Suriname (Batista et al. 2008) e em todas as regiões do Brasil (Barros et al. 2014). Ocasional na área $\mathrm{e}$ observada apenas no período chuvoso. Diferenciase das demais espécies do gênero na área pelas pétalas inteiras com ápice obtuso e labelo inteiro.

17. Habenaria petalodes Lindl., Gen. Sp. Orchid. Pl. 3161835.

Fig. $3 b$

Terrícolas. Caule $28-42 \mathrm{~cm}$ compr., cilíndrico. Folhas 7-10, 7-12,5 × 2,3-3 cm, presentes na floração, distribuídas ao longo do caule, convolutas, linear-lanceoladas, ápice agudo. Inflorescência terminal, racemo; pedúnculo 4,5-6 cm compr.; raque $13-28 \mathrm{~cm}$ compr. Flores ressupinadas, calcaradas, cálcar 1,8-2 cm compr., esverdeadas; sépala dorsal 7-9 × 5-6 mm, ovada, ápice obtuso, sépalas laterais 7-11 × 3-4,5 mm, obovado-falcadas, ápice agudo; pétalas 6,5-9 $\times$ 4-5 mm, espatuladas, ápice truncado-sinuoso, inteiras; labelo 9-11 × 1-1,3 mm, linear-oblongo, ápice agudo, inteiro, margem inteira; coluna $3-3,5$ mm compr.; polínias 2 ; ovário pedicelado $1,6-1,8$ $\mathrm{cm}$ compr. Fruto não observado.

Material examinado: Agrestina, 16.VII.2007, fl., $P$. Gomes et al. 422 (UFP).Bezerros, 31.VII.2005, fl., $P$. Gomes et al. 101 (UFP). Caruaru, 11.IX.2009, fl., M. Sobral-Leite et al. 1014 (UFP).

Habenaria petalodes ocorre no Paraguai (Batista et al. 2008) e amplamente distribuída no Brasil (Barros et al. 2014). Ocasional na área, sendo observada apenas no período chuvoso com ocorrência em ambientes sombreados no interior das ilhas de vegetação. Pode ser diferenciada das demais espécies do gênero por possuir pétalas de ápice truncado-sinuoso.

18. Habenaria pratensis (Lindl.) Rchb.f., Linnaea 22: 813. 1850.

Fig. 3c

Terrícolas. Caule ca. $14 \mathrm{~cm}$ compr., cilíndrico. Folhas 5, 7-12 × 1-1,2 cm, presentes na floração, distribuídas ao longo do caule, convolutas, linearlanceoladas, ápice acuminado. Inflorescência terminal, racemo; pedúnculo ca. 5,5 cm compr., raque ca. $6,5 \mathrm{~cm}$ compr. Flores ressupinadas, calcaradas, cálcar 2,3-2,8 cm compr., amareladas; sépala dorsal ca. $13 \times 8 \mathrm{~mm}$, ovada, ápice agudo, sépalas laterais $14-15 \times 4,5-5 \mathrm{~mm}$, ovado-lanceoladas, ápice acuminado; pétalas bipartidas, segmento anterior $8-11 \times 1 \mathrm{~mm}$, linear, ápice agudo, segmento posterior 13-14 $\times$ 5-6 mm, elíptico-falcado, ápice agudo; labelo profundamente tripartido, segmentos laterais 10-11 $\times 1-1,5 \mathrm{~mm}$, linear-oblanceolados a oblanceolados, ápice agudo, segmento mediano ca. $13 \times 8 \mathrm{~mm}$, trapezoidal, ápice agudo, margem sinuosa; coluna 3-3,5 mm compr.; polínias 2; ovário pedicelado $3-3,3 \mathrm{~cm}$ compr. Fruto não observado.

Material examinado: Jaqueira: 17.VIII.2010, fl., M.A. Chagas et al. 20 (UFP). Maraial, 22.IX.2006, fl., M. Sobral-Leite et al. 174 (UFP).

Habenaria pratensis ocorre nas Regiões Nordeste, Centro-Oeste e Sul do Brasil (Barros et al. 2014). Rara no local, florescendo logo após as chuvas. Pode ser diferenciada das demais espécies de Habenaria registradas na área de estudo pelos segmentos laterais do labelo linear-oblanceolados a oblaceolados.

19. Habenaria trifida Kunth, Nov. Gen. Sp. 1: 330 1816.

Fig. 3d

Terrícolas. Caule 24-30 cm compr., cilíndrico. Folhas 3-5, 4-9 × 1,2-1,7 cm, presentes na floração, distribuídas ao longo do caule, convolutas, linear-lanceoladas, ápice acuminado. Inflorescência terminal, racemo; pedúnculo 6-8 cm compr., raque ca. $4 \mathrm{~cm}$ compr. Flores ressupinadas, calcaradas, cálcar $6-8,5 \mathrm{~cm}$ compr., branco-esverdeadas; sépala dorsal ca. 11 $\times 7,5 \mathrm{~mm}$, ovada, ápice agudo, sépalas laterais ca. $13 \times 5,5 \mathrm{~mm}$, ovado-falcadas, ápice agudo; pétalas bipartidas, segmento anterior $9-10 \times 1 \mathrm{~mm}$, linear, ápice agudo, segmento posterior 11-12 $\times$ 2-2,5 mm, oblongo-falcado, ápice agudo; labelo tripartido, segmentos laterais $12-13 \times 2 \mathrm{~mm}$, lineares, ápice agudo, segmento mediano ca. $17 \times$ $2 \mathrm{~mm}$, linear, ápice agudo, margem inteira; coluna 3-4 mm compr.; polínias 2 ; ovário pedicelado $6-10,5 \mathrm{~cm}$ compr. Fruto não observado.

Material examinado: Agrestina, 12.V.2007, fl., $P$. Gomes et al. 342 (UFP). Bezerros, 31.VII.2005, fl., P. Gomes et al. 82 (UFP). Maraial, 20.V.2007, fl., M. Sobral-Leite et al. 362 (UFP).

Habenaria trifida ocorre desde o México à América do Sul (Batista et al. 2008), sendo amplamente distribuída no Brasil (Barros et al. 2014). É ocasional na área, ocorrendo no período chuvoso. Diferencia-se das demais espécies do gênero pelo cálcar maior ou igual a $6 \mathrm{~cm}$ compr. 

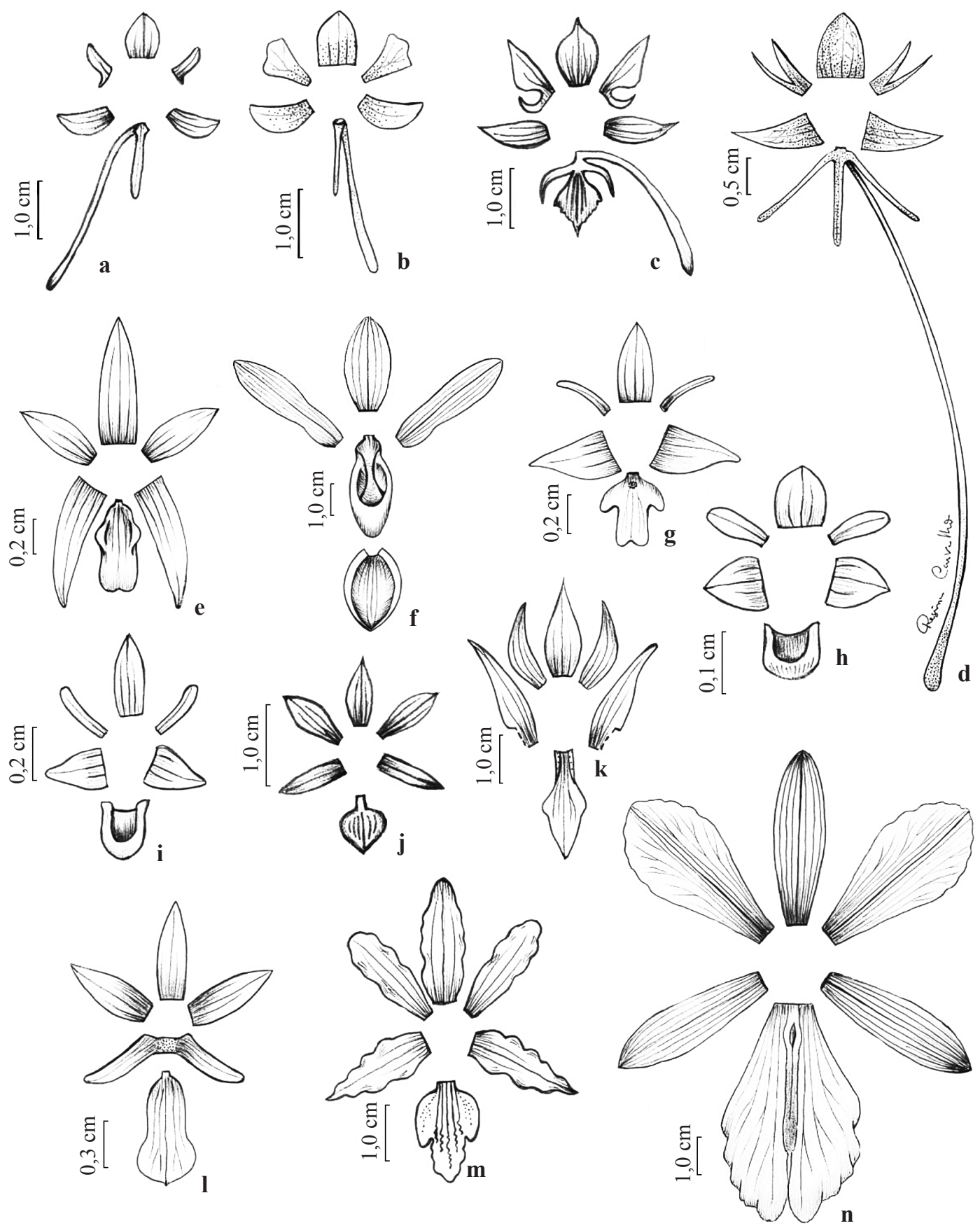

Figura 3 - Perianto - a. Habenaria obtusa; b. Habenaria petalodes; c. Habenaria pratensis; d. Habenaria trifida; e. Octomeria alexandri; f. Phragmipedium lindleyanum; g. Polystachya estrellensis; h. Prescottia oligantha; i. Prescottia plantaginifolia; j. Prosthechea alagoensis; k. Sacoila lanceolata; 1. Scaphyglottis fusiformis; m. Schomburgkia gloriosa; n. Sobralia liliastrum.

Figure 3 - Dissected perianth - a. Habenaria obtusa; b. Habenaria petalodes; c. Habenaria pratensis; d. Habenaria trifida; e. Octomeria alexandri; f. Phragmipedium lindleyanum; g. Polystachya estrellensis; h. Prescottia oligantha; i. Prescottia plantaginifolia; j. Prosthechea alagoensis; k. Sacoila lanceolata; 1. Scaphyglottis fusiformis; m. Schomburgkia gloriosa; n. Sobralia liliastrum. 
20. Octomeria alexandri Schltr., Anexos Mem. Inst. Butantan, Secç. Bot. 1(4): 53. $1922 . \quad$ Fig. 3e

Rupícolas. Ramicaule 3,5-8 cm compr., cilíndrico. Folha 1, 5,5-7,5 ×0,2-0,4 cm, presente na floração, apical, cilíndrica, linear, crassa, ápice agudo. Inflorescência terminal, fascículo, flores abrem em 1-2 por vez, pedúnculo inconspícuo; raque ca. $4 \mathrm{~mm}$ compr. Flores ressupinadas, amareladas, não calcaradas; sépala dorsal 7-8 $\times$ $2 \mathrm{~mm}$, lanceolada, ápice agudo, sépalas laterais $7,5-8 \times 2-2,5 \mathrm{~cm}$, lanceoladas, ápice agudo; pétalas 5-6 × 2-2,5 mm, elíptico-lanceoladas, ápice agudo; labelo 4,5-5 × 2,5-3 mm, trilobado, ápice truncado, margem inteira; dois calos lamelares no disco; coluna ca. $2 \mathrm{~mm}$ compr., polínias 8 , inteiriças; ovário pedicelado $2-3 \mathrm{~mm}$ compr. Fruto não observado.

Material examinado: Jaqueira, 31.I.2013, fl., E. Pessoa et al. 1065 (UFP).

Octomeria alexandri tem distribuição conhecida apenas para os estados do Rio Grande do Sul, São Paulo, Rio de Janeiro e Bahia (Barros et al. 2014). É um novo registro para Pernambuco, sendo este o limite norte da sua distribuição. É conhecida uma única população num afloramento com matriz de Floresta Atlântica a ca. de 700 m de altitude. Vegetativamente é confundida com Brassavola tuberculata, da qual se diferencia por caracteres florais, como flores menores, solitárias ou reunidas em fascículos.

21. Phragmipedium sargentianum (Rolfe) Rolfe, Orchid Rev. 4: 332. 1896.

Fig. $3 f$

Terrícolas. Caule 3-4 cm compr., cônico. Folhas 6-8, 19-44 × 2-4,4 cm, presentes na floração, em rosetas basais, conduplicada, linear-lanceoladas, ápice agudo, assimétrico. Inflorescência terminal, racemo; pedúnculo 59-82 cm compr.; raque 13-15 cm compr. Flores ressupinadas, amarelo avermelhadas, não calcaradas; sépala dorsal 2,4-2,9 × 1,3-1,5 cm, ovado-elíptica, ápice obtuso, velutina externamente, sépalas laterais 2,4-2,6 $\times 1,8-2 \mathrm{~cm}$, totalmente conadas, largo-elípticas, ápice obtuso, velutinas externamente; pétalas 3,9-4,3 × 0,5-0,9 cm, oblongas, ápice emarginado, apicalmente ciliada; labelo 2,7-3,5 × 1,1-1,8 cm, saquiforme, ápice arredondado, margem inteira, internamente velutino; coluna 7-10 mm compr.; pólen desagregado; ovário pedicelado 4,7-5,5 cm compr. Fruto não observado.

Material examinado: Bonito, 10.I.2012, st., E. Pessoa et al. 897 (UFP). Lagoa dos Gatos,17.XII.2010, fl., E. Pessoa \& A. Melo 435 (UFP).
Phragmipedium sargentianum espécie endêmica do Nordeste do Brasil, com distribuição conhecida apenas para os estados de Alagoas, Bahia e Pernambuco (Barros et al. 2014). Rara na área e relacionada à matriz circundante de Floresta Atlântica, ocorrendo em afloramentos mais úmidos. Está citada na lista de espécies ameaçadas de extinção do Ministério do Meio Ambiente (2008) e por Menini Neto et al. (2013). Pode ser facilmente diferenciada na área pelo labelo saquiforme e sépalas velutinas.

22. Polystachya estrellensis Rchb.f., Linnaea 25: 2311852.

Fig. $3 g$

Rupícolas. Pseudobulbo 7-15 mm compr., ovóide, homoblástico. Folhas 2-4, 6-16 × $0,8-2,2 \mathrm{~cm}$, presentes na floração, distribuídas ao longo do caule, conduplicadas, elípticas, ápice obtuso. Inflorescência terminal, racemo ou panícula; pedúnculo 4-13,5 cm compr.; raque 2-10 cm compr. Flores não ressupinadas, amareloesverdeadas, não calcaradas; sépala dorsal 2,5-3 $\times$ 1-1,2 mm, lanceolada, ápice agudo, sépalas laterais 3-4,5 × 2,3-3,2 mm, deltóides, ápice agudo; pétalas 2,2-3 $\times 0,3-0,6 \mathrm{~mm}$, estreito-oblanceoladas, ápice agudo; labelo ca. $4 \times 3 \mathrm{~mm}$, trilobado, ápice arredondado, margem inteira; coluna 1-2 mm compr.; polínias 2; ovário pedicelado 1,5-4 mm compr. Fruto 1-1,2 $\times 0,2 \mathrm{~cm}$, fusiforme.

Material examinado: Agrestina, 25.IV.2008, fl., $P$. Gomes 833 (UFP). Bezerros, 17.V.2013, fl., J.L. CostaLima 937 (RB, UFP). Jaqueira, 30.V.2012, fl. e fr., $E$. Pessoa 939 (RB, UFP).

Polystachya estrellensis é amplamente distribuída nos trópicos (Govaerts et al. 2014), e também em todas as regiões do Brasil (Barros et al. 2014). É ocasional nas áreas cuja matriz é de Floresta Atlântica. Distingue-se das demais espécies por possuir pseudobulbos ovóides e curtos $(0,7-1,5 \mathrm{~cm}$ compr.), além de flores não ressupinadas.

23. Prescottia oligantha (Sw.) Lindl., Gen. Sp. Orchid. Pl.: 454. $1840 . \quad$ Fig. 3h

Terrícolas. Caule inconspícuo, subterrâneo, 5-7 mm compr., elipsóide. Folhas 2-3, 3-4,5 × $1,1-1,4 \mathrm{~cm}$, presentes na floração, em rosetas basais, convolutas, elípticas, ápice agudo. Inflorescência terminal, espiga; pedúnculo $16,5-22,5 \mathrm{~cm}$ compr., raque 5,7-12,5 cm compr. Flores não ressupinadas, alvas, não calcaradas; sépala dorsal 1,1-1,2 × 0,8-0,9 mm, ovada, ápice 
arredondado, sépalas laterais 1,1-1,5 × 0,9-1 mm, ovadas, ápice arredondado; pétalas 0,9-1 × 0,5 $\mathrm{mm}$, oblongas, ápice arredondado; labelo 1-1,1 $\times 12 \mathrm{~mm}$, cuculado, ápice arredondado, margem inteira; coluna $0,4-0,5 \mathrm{~mm}$ compr.; polínias 4 ; ovário pedicelado $0,8-1,1 \mathrm{~cm}$ compr. Fruto $3-4 \times$ 2-2,2 mm, globoso.

Material examinado: Lagoa dos Gatos, 17.XII.2010, fr., E. Pessoa \& A. Melo 433 (UFP). São Caitano, 26.X.2010, fl., K. Mendes \& P. Gomes 567 (UFP).

Prescottia oligantha é amplamente distribuída na Região Neotropical (Govaerts et al. 2014), e em todas as regiões do Brasil (Barros et al. 2014). Ocasional na área. Diferencia-se da outra espécie do gênero pelo menor porte.

24. Prescottia plantaginifolia Lindl., Exot. Fl.: 115. 1824.

Fig. $3 i$

Terrícolas. Caule inconspícuo, subterrâneo, 5-20 mm compr., elipsóide. Folhas 3-7, 6,5-20 $\times 1,6-3,5 \mathrm{~cm}$, presentes na floração, distribuídas ao longo do caule em rosetas basais, convolutas, elípticas, ápice agudo. Inflorescência terminal, espiga; pedúnculo 16-29,5 cm compr., raque 7-30 $\mathrm{cm}$ compr. Flores não ressupinadas, esverdeadas, não calcaradas; sépala dorsal 2,3-2,7 × 1,1-1,3 mm, elíptica, ápice agudo, sépalas laterais 2,2-2,5 × 1,3 $\mathrm{mm}$, ovadas, ápice agudo; pétalas $2,3-2,5 \times 0,5-0,8$ $\mathrm{mm}$, oblongas, ápice redondo; labelo 2-2,5 $\times 2 \mathrm{~mm}$, cuculado, ápice agudo, margem inteira; coluna ca. $1 \mathrm{~mm}$ compr.; polínias 4; ovário pedicelado 2,1-3 $\mathrm{mm}$ compr. Fruto $3-5 \times 2 \mathrm{~mm}$, elipsóide.

Material examinado selecionado: Agrestina, 23.IX.2007, fl., P. Gomes et al. 572 (UFP). Camocim de São Félix, 9.I.2012, fr., E. Pessoa et al. 873 (UFP). São Caitano, 28.VIII.2010, fl., K. Mendes et al. 505 (NY, RB, UFP). Triunfo, 12.I.2012, st., E. Pessoa et al. 917 (UFP).

Prescottia plantaginifolia é amplamente distribuída no Brasil (Barros et al. 2014). Abundante na área de estudo, anual e com floração rápida. Diferencia-se da outra espécie do gênero por serem plantas de maior porte.

25. Prosthechea alagoensis (Pabst) W.E. Higgins, Phytologia 82: 376. 1997. Fig. $3 \mathrm{j}$

Rupícolas. Pseudobulbo 3-5,5 cm compr., fusiforme a cilíndrico, heteroblástico. Folhas 2, $5,5-8 \times 0,5-0,7 \mathrm{~cm}$, presentes na floração, apicais, conduplicadas, linear-elípticas, ápice arredondado. Inflorescência terminal, racemo; pedúnculo 5-10 mm compr.; raque 3-7 mm compr. Flores não ressupinadas, alvo amareladas com estrias róseas, não calcaradas; sépala dorsal $1,1-1,2 \times 0,25-0,3$ $\mathrm{cm}$, oblonga, ápice agudo, sépalas laterais 1,1-1,2 $\times 0,3-0,35 \mathrm{~cm}$, oblongas a elípticas, ápice agudo; pétalas 1,1-1,2 ×0,3-0,35 cm, oblanceoladas, ápice agudo; labelo $0,9-1 \times 0,5-0,55 \mathrm{~cm}$, ungliculado, ovado, ápice obtuso, margem inteira; coluna 5-6 mm compr.; polínias 4; ovário pedicelado 6-10 mm compr. Fruto 1,5-2 × 1,0-1,2 cm, obovóide, tri-alado. Material examinado: Jaqueira, 31.I.2013, fl. e fr., E. Pessoa et al. 1061 (RB, UFP).

Prosthechea alagoensis é endêmica do Brasil, ocorrendo apenas na Região Nordeste (Barros et al. 2014). Rara nos afloramentos rochosos, sendo mais comum no interior da Floresta Atlântica circundante. Diferencia-se das demais espécies por possuir pseudobulbos fusiformes a cilíndricos e flores não ressupinadas.

26. Sacoila lanceolata (Aubl.) Garay, Bot. Mus. Leafl. 28: 3521980 (1982). $\quad$ Fig. 3k

Terrícolas. Caule inconspícuo, subterrâneo, 5-20 mm compr., elipsóide. Áfila na floração. Inflorescência terminal, racemo; pedúnculo $28-57,5 \mathrm{~cm}$ compr., raque $7-25,5 \mathrm{~cm}$ compr. Flores ressupinadas, com mento, mento $8-11 \mathrm{~mm}$ compr., róseas a avermelhadas; sépala dorsal 1,7-2,2 $\times 0,5-0,8 \mathrm{~cm}$, laceolada, ápice agudo, sépalas laterais 2-2,9 ×0,4-0,6 cm, elíptico-lanceoladas, ápice agudo; pétalas 1,4-2 ×0,4-0,6 cm, elípticofalcadas, ápice agudo; labelo 1,2-1,5 × 0,7-0,9 cm, trilobado, ápice agudo, margem inteira; coluna 7-9 mm compr.; polínias 2; ovário pedicelado 1,2-1,7 $\mathrm{cm}$ compr. Fruto não observado.

Material examinado selecionado: Belo Jardim, 11.I.2012, fl., E. Pessoa et al. 911 (NY, RB, UFP). Bezerros, 17.I.2010, fl., E. Pessoa \& M. Alves 251 (RB, UFP). Bonito, 9.I.2012, fl., E. Pessoa et al. 877 (RB, UFP). Buíque, 25.II.2002, fl., I. Machado (UFP- 31.777). São Caitano, 3.XII.2010, fl., E. Pessoa \& K. Mendes 405 (UFP). Triunfo, 12.I.2012, fl., E. Pessoa et al. 919 (NY, RB, UFP).

Sacoila lanceolata é amplamente distribuída na região Neotropical (Govaerts et al. 2014), e também no Brasil (Barros et al. 2014). Abundante, especialmente em ambientes antropizados. Pode ser diferenciada das demais espécies da área pela ausência de folhas na antese e pelas flores róseas a avermelhadas com mento.

27. Scaphyglottis fusiformis (Griseb.) R.E. Schult., Bot. Mus. Leafl. 17(7): 205. $1956 . \quad$ Fig. 31

Rupícolas. Pseudobulbo 2,5-8 cm compr., fusiforme, heteroblástico, sobreposto. Folha 1, $2-7,5 \times 0,3-0,4 \mathrm{~cm}$, apical, conduplicada, linear, ápice emarginado. Inflorescência terminal, racemo; 
pedúnculo 1-1,2 cm compr.; raque 4-4,5 mm compr. Flores ressupinadas, alvas; sépala dorsal ca. $6 \times 1,5-2,5 \mathrm{~mm}$, lanceolada, ápice agudo, sépalas laterais $6,5-7,5 \times 1,5-3 \mathrm{~mm}$, lanceoladas, ápice agudo; pétalas ca. $6 \times 2 \mathrm{~mm}$, elípticas, ápice agudo; labelo 6,5-8 $\times 4 \mathrm{~mm}$, obovado, ápice cuspidado, margem inteiro; coluna 4,2-5 mm compr.; polínias 2, ovário pedicelado 1,2-2 cm compr. Fruto 1,9-2,3 $\times 0,15-0,25 \mathrm{~cm}$, fusiforme.

Material examinado: Jaqueira, 30.I.2013, fl. e fr., $D$. Araújo 2409 (UFP).

Scaphyglottis fusiformis ocorre desde a Costa Rica até o Brasil (Govaerts et al. 2014), onde é amplamente distribuída (Barros et al. 2014). Rara como rupícola na área de estudo, porém é comum como epífita na Floresta Atlântica circundante. Pode ser facilmente diferenciada das demais espécies da área por possuir pseudobulbos sobrepostos.

28. Schomburgkia gloriosa Rchb.f., Hamburger Garten- Blumenzeitung 16: 178. 1860. Fig. 3m

Rupícolas. Pseudobulbo 15-17 cm compr., fusiforme, heteroblástico. Folhas 2, 20-21 × 3-4,5 $\mathrm{cm}$, presentes na floração, apicais, conduplicadas, elípticas a oblongas, ápice arredondado. Inflorescência terminal, racemo; pedúnculo ca. $49 \mathrm{~cm}$ compr.; raque ca. 4,1 cm compr. Flores ressupinadas, artropurpúreas, não calcaradas; sépala dorsal 1,8-2,5 × 0,4-0,7 cm, lanceolada, ápice agudo, sépalas laterais $1,8-2,1 \times 0,6-0,7 \mathrm{~cm}$, lanceoladas, ápice agudo; pétalas 1,7-2,1 ×0,5-0,6 $\mathrm{cm}$, elíptico-lanceoladas, ápice acudo; labelo 1-1,8 $\times 0,7-1,2 \mathrm{~cm}$, trilobado, lobos laterais, 2-4 × 6-9 $\mathrm{mm}$, sub-ovóides, ápice agudo, lobo mediano 8-10 × 3,5-7 mm, oblongo, ápice obtuso, margem ondulada; calos lamelares no disco; coluna 1,2-1,3 cm compr.; polínias 8 ; ovário pedicelado 4,5-6,5 $\mathrm{cm}$ compr. Fruto não observado.

Material examinado: Agrestina, 18.XI.2010, fl., $M$. Sobral-Leite \& P. Gomes 1203 (UFP)

Schomburgkia gloriosa ocorre no norte da América do Sul (Govaerts et al. 2014) e nas Regiões Norte, Nordeste, Centro-Oeste e Sudeste do Brasil (Barros et al. 2014). Rara na área, sendo conhecida de um afloramento rochoso e com poucos indivíduos. A coloração atropurpúrea das flores é distinta do padrão morfológico usualmente observado em que as flores são acastanhadas. Pode-se diferenciá-la das demais espécies da área de estudo pelos pseudobulbos fusiformes e com duas folhas apicais e as inflorescências com raque curta (ca. $4 \mathrm{~cm}$ compr.).
29. Sobralia liliastrum Lindl., Gen. Sp. Orchid. P1.: 177. 1833.

Fig. 3n

Terrícolas. Caule 90-129 cm compr., cilíndrico. Folhas 5-6, 4,5-18,5 × 0,9-2,4 cm, presentes na floração, distribuídas ao longo do caule, plicadas, lanceoladas a elípticas, ápice agudo. Inflorescência terminal, racemo; pedúnculo ca. $1 \mathrm{~cm}$ compr.; raque $2-5,5 \mathrm{~cm}$ compr. Flores ressupinadas, alvas, não calcaradas; sépala dorsal $5,3-6 \times 1,5-1,6 \mathrm{~cm}$, oblongas, ápice agudo, sépalas laterais $5,2-5,9 \times 1,3-1,7 \mathrm{~cm}$, oblongas, ápice agudo a cuspidado; pétalas 5,4-6,2 × 2,2-2,8 $\mathrm{cm}$, oblanceoladas, ápice obtuso; labelo 6,2-6,4 $\times 3,3-4,2 \mathrm{~cm}$, obovado, ápice bilobado, margem ondulada, calos lamelares desde a base até o disco; coluna 2,5-3,6 cm compr., ápice com dois apêndices laterais; polínias 8 ; ovário pedicelado 1,6-2,2 cm compr. Fruto não observado.

Material examinado: Bezerros, 18.XI.2005, f1., $P$. Gomes et al. 170 (UFP). Bonito, 10.I.2012, fl., E. Pessoa et al. 896 (RB, UFP). Jaqueira: 17.VIII.2010, fl., A. Melo et al. 459 (UFP). Lagoa dos Gatos, 17.XII.2010, fl., E. Pessoa \& A. Melo 432 (RB, UFP).

Sobralia liliastrum ocorre no norte da América do Sul (Govaerts et al. 2014) e nas Regiões Norte, Nordeste, Centro-Oeste e Sudeste do Brasil (Barros et al. 2014). Abundante na área e relacionada aos afloramentos rochosos cuja matriz é de Floresta Atlântica. Suas populações são grandes e os indivíduos podem formar ilhas de vegetação monoespecíficas. São facilmente diferenciadas das demais espécies da área pelas folhas plicadas e flores brancas e vistosas.

\section{Agradecimentos}

Às instituições que financiaram esse estudo, como CAPES, CNPq, NSF e The Beneficia Foundation. Os autores também agradecem a Regina Carvalho as ilustrações e aos principais coletores de Orchidaceae dos afloramentos rochosos de Pernambuco, incluindo Leonardo Pessoa Felix, Marcelo Sobral-Leite e Polyhanna Gomes.

\section{Referências}

Ab'Sáber, A.N. 1999. Dossiê Nordeste seco. Estudos Avançados 13: 5-59.

Ab'Sáber, A.N. 2003. Os domínios da natureza no Brasil: potencialidades paisagísticas. Ateliê Editorial, São Paulo. 159p.

Andrade-Lima, D. 1982. Present-day forest refuges in northeastern Brazil. In: Prance, G.T. (ed.). Biological diversification in the tropics. Columbia University Press, New York. Pp. 247-251. 
Barros, F.; Vinhos, F.; Rodrigues, V.T.; Barberena, F.F.V.A.; Fraga, C.N. \& Pessoa, E.M.; Forster, W. \& Menini Neto, L. 2014. Orchidaceae. In: Lista de espécies da flora do Brasil. Jardim Botânico do Rio de Janeiro. Disponível em $<$ http://floradobrasil. jbrj.gov.br/jabot/floradobrasil/FB179>. Acesso em 20 março 2014.

Batista, J.A.N.; Silva, J. \& Bianchetti, L.B. 2008. The genus Habenaria (Orchidaceae) in the Brazilian Amazon. Revista Brasileira de Botânica 31: 105-134.

Burke, A. 2002. Island-matrix relationships in Nama Karoo inselberg landscapes. Part I: Do inselbergs provide a refuge for matrix species? Plant Ecology 160: 79-90.

Carnevali, G. \& Ramírez-Morillo, I.M. 2003. Orchidaceae. In: Berry, P. E.; Holst, K. \& Yatskievych, K. (eds.). Flora of the Venezuelan Guayana. Vol. 7. Missouri Botanical Garden, St. Louis. Pp. 200-619.

Chase, M.W.; Williams, N.H.; Faria, A.D.; Neubig, K.M.; Amaral, M.C. \& Whitten. W.M. 2009. Floral convergence in Oncidiinae (Cymbidieae; Orchidaceae): an expanded concept of Gomesa and a new genus Nohawilliamsia. Annals of Botany 104: 387-402.

Dressler, R.L. 2005. How many orchid species? Selbyana 26: $155-158$.

Dressler, R.L. 1993. Phylogeny and classification of the orchid family. Dioscorides Press, Portland. 314p.

Dunsterville, G.C.K. \& Garay, L.A. 1966. Venezuelan orchids illustrated, IV. Andre Deutsch, London. $332 \mathrm{p}$.

Felix, L.P. \& Carvalho, R. 2002. Diversidade de orquídeas no estado de Pernambuco. In: Tabarelli, M. \& Silva, J.M.C. (eds.). Diagnóstico da biodiversidade de Pernambuco. Vol. 1. Ed. Massangana, Recife. Pp. 207-217.

França, F.; Melo, E.; Santos, A.K.A.; Melo, J.G.A.N.; Marques, M.; Silva-Filho; M.F.B.; Moraes, L. \& Machado, C. 2005. Estudo ecológico e florístico em ilhas de vegetação de um inselberg no semi-árido da Bahia, Brasil. Hoehnea 32: 93-101.

França, F.; Melo, E. \& Miranda, J.G. 2006. Aspectos da diversidade da vegetação no topo de um inselberg no semi-árido da Bahia, Brasil. Sitientibus 6: 30-35.

Gomes, P. \& Alves, M. 2009. Floristic and vegetational aspects of an inselberg in the semi-arid region of Northeast Brazil. Edinburgh Journal of Botany 66: 1-18.

Gomes, P. \& Alves, M. 2010. Floristic diversity of two crystalline rocky outcrops in the Brazilian northeast semi-arid region. Revista Brasileira de Botânica. 33: 661-676.
Gomes-Ferreira, A.B. 1990. Levantamento das orquídeas do nordeste oriental do Brasil. In: Valle, L.F. (ed.). II encontro nacional de orquidófilos e orquidólogos. Expressão e Cultura, Rio de Janeiro. Pp. 13-38.

Govaerts, R.; Pfahl, J.; Campacci, M.A.; Holland Baptista, D.; Tigges, H.; Shaw, J.; Cribb, P.; George, A.; Kreuz, K. \& Wood, J. 2014. World checklist of Orchidaceae. The Board of Trustees of the Royal Botanic Gardens, Kew. Disponível em $<$ http://apps. kew.org/wcsp/>. Acesso em 9 março 2014.

Jacomine, P.K.T.; Cavalcanti, A.C.; Burgos, N.; Pessoa, S.C.P. \& Silveira, C.O. 1973. Levantamento exploratório - Reconhecimento de solos do estado de Pernambuco. SUDENE/DNPE, Recife. 359p.

Kluge, M. \& Brulfert, J. 2000. Ecophysiology of vascular plants on inselbergs. In: Porembski, S. \& Barthlott, W. (eds.). Inselbergs: biotic diversity of isolated rock outcrops in tropical and temperate regions. Springer-Verlag, Berlin. Pp. 143-174.

Martinelli, G. 2007. Mountain biodiversity in Brazil. Revista Brasileira de Botânica 30: 587-597.

Melo, M.C. \& Borba, E.L. 2011. Morphological variability in rupicolous species of the Acianthera prolifera complex (Orchidaceae) occurring in southeastern Brazil. Plant Systematics and Evolution 293: 135-145.

Menini Neto, L.; Barros, F.; Vinhos, F.; Furtado, S.G.; Judice, D.M.; Fernandez, E.P.; Sfair, J.C.; Barros, F.S.M.; Prieto, P.V.; Kutschenko, D.C.; Moraes, M.A.; Zanata, M.R.V.; Santos Filho, L.A.F. 2013. Orchidaceae. In: Martinelli, G. \& Moraes, M.A. (eds.). Livro vermelho da flora do Brasil. Jardim Botânico do Rio de Janeiro, Rio de Janeiro. Pp. 749-818.

Ministério do Meio Ambiente. 2008. Lista oficial das espécies da flora brasileira ameaçadas de extinção. Instrução Normativa Ministério do Meio Ambiente $n^{\circ}$ 06/2008. Disponível em <www.ibama.gov.br/ sisbio $>$. Acesso em 3 setembro 2009.

Moraes, L.J.M. 1977. Serras e Montanhas do Nordeste. ESAM, Mossoró. 122p.

Mori, S.A.; Mattos-Silva, L.A.; Lisboa, G. \& Coradin, L. 1985. Manual de manejo do herbário fanerogâmico. $2^{a}$ ed. CEPLAC/CEPEC, Ilhéus. 104p.

Pessoa, E.; Alves, M.; Alves-Araújo, A.; Palma-Silva, C. \& Pinheiro, F. 2012. Integrating different tools to disentangle species complexes: a case study in Epidendrum (Orchidaceae). Taxon 61: 721-734.

Porembski, S. \& Barthlott, W. 2000. Inselbergs: biotic diversity of isolated rock outcrops in tropical and temperate regions. Ecological Studies 146. Springer-Verlag, Berlin. 522p.

Porembski, S.; Martinelli, G.; Ohlemuller, R. \& Barthlott, W. 1998. Diversity and ecology of saxicolous 
vegetation mats on inselbergs in the Brazilian Atlantic rainforest. Diversity and Distributions 4: 107-119.

Rasmussen, F.N. 1985. Orchidaceae. In: Dahlgren, R.M.T.; Clifford, T. \& Yeo, P.F. (eds.). The families of the monocotyledons. Springer-Verlag, Berlin. Pp. 249-274.

Silva, F.B.R.; Riché, G.R.; Tonneau, J.P.; Souza Neto, N.C.; Brito, L.T.L.; Correia, R.C.; Cavalcanti, A.C.; Silva,
F.H.B.B.; Silva, A.B.; Araújo Filho, J.C. \& Leite, A.P. 1993. Zoneamento agroecológico do Nordeste, diagnóstico do quadro natural e agrossocioeconômico. Embrapa, Petrolina. 387p.

Thiers, B. [continuously updated]. Index herbariorum: a global directory of public herbaria and associated staff. New York Botanical Garden's Virtual Herbarium. Disponível em $<$ http://sweetgum.nybg. org/ih/>. Acesso em 8 março 2014.

\section{Lista de exsicatas}

Alcântara, G.D. 7(6); Alves, J.L. s.n. UFP s.n. UFP 34.708(8); 34.711(5); Alves, M. et al. 29895(5); 31895(8); 34545(9); Alves, M. \& Luceño, M. s.n. UFP 11062(1); Alves-Araújo, A. 74(11); Amorim, B.S. 1127(10); 1409(9); Andrade-Lima, D. 59-3354(9); D. Araújo, D. et al. 2409(27); Baracho, G.S. \& Siqueira-Filho, J.A. 329(5); 334(24); Buril, M.T. 403(6); Chagas, M.A. et al. 20(18); Correia, M. 376(5); Costa-Lima, J.L. 721(16); Felix, L.P. et al. 795(18); 1052(19); 1700(19); 1702(16); 6647(21); 6650(11); 6657(15); 6919(18); 7043(11); 7047(3); 7188(24); 7189(14); 7206(18); 7207(19); 8311(1); 8312(29); 8403(19); 8467(11); 8910(16); 8917(24); s.n. UFP 5.826(5); s.n. UFP 21.259(21); s.n. UFP 21.273(11); Ferreira, C. s.n. IPA 63185(12); Fontana, A.P. 6551(1); 6985(1); 7074(1); Gomes, P. et al. 17(1); 82(19); 83(17); 101(17); 103(16); 103a(18); 152(11); 166(13); 169(13); 170(29); 172(13); 186(8); 188(7); 199(3); 263(1); 339(1); 342(19); 417(10); 422(17); 572(24); 592(24); 666(9); 669(9); 683(5); 833(22); 856(16); 917(24); Liebig, A. et al. 66(2); Luceño, M. 322(1); Machado, I.C. s.n. UFP 22.866(8); s.n. UFP 31.719(1); s.n. UFP 31.777(26); s.n. UFP 46.135(11); Melo, A. et al. 459(29); Mendes, K. 498(24); 505(24); 699(16); 713(16); Mendes, K. \& Gomes, P. 567(23); Miranda, A.M. et al. 1088(11); 1321(8); 1451(8); 1571(29); 1664(8); 1674(12); 2568(3); 2693(14); 2713(14); 2717(14); 3544(14); Oliveira, C.R.S. 166(1); 172(7); Oliveira, J.B.S. 69(8); Oliveira, M. 1835(1); Pessoa, E. et al. 92(5); 93(16); 94(11); 95(1); 498(5); 505(8); 609(16); 610(11); 870(3); 871(5); 872(1); 873(24); 874(11); 875(8); 877(26); 883(8); 884(29); 885(5); 886(11); 894(8); 895(11); 896(29); 897(21); 898(12); 903(11); 905(13); 908(7); 909(8); 910(3); 911(26); 912(1); 916(7); 917(24); 918(1); 919(26); 920(5); 921(4); 939(22); 1061(25); 1065(20); Pessoa, E. \& Alves, M. 246(11); 247(8); 250(3); 251(26); 253(7); 254(5); 409(11); Pessoa, E. \& Melo, A. 432(29); 433(23); 435(21); Pessoa, E. \& Mendes, K. 300(2); 304(13); 305(5); 306(9); 315(1); 316(24); 318(3); 319(6); 320(16); 321(16); 405(26); 406(23); 411(7); 916(7); Schlindwein, C. s.n. UFP 31.772(5); Siqueira-Filho, J.A. 1175(18); 1202(25); 1237(1); 1253(24); 1263(1); 1264(14); 1287(7); 1288(5); 1495(1); 2388(22); 2479(1); Siqueira-Filho, J.A. \& Baracho, G.S. 759(5); Siqueira-Filho, J.A. \& Campelo, M.J. 732(29); Siqueira-Filho, J.A. \& Felix, L.P. 1423(21); Siqueira-Filho, J.A. \& Leme, E. 1486(3); Silva, K.A. et al. 92(6); Silva, S.M. et al. 26(6); Sobral-Leite, M. et al. 174(18); 237(5); 354(1); 362(19); 565(29); 575(5); 603(5); 710(1); 742(8); 809(19); 812(15); 857(17); 858(17); 859(24); 884(10); 885(8); 915(15); 918(3); 933(1); 972(16); 995(3); 996(11); 1014(17); 1051(5); 1070(16); 1076(24); 1077(13); 1087(5); 1089(1); 1092(3); 1213(26); 1240(17); Sobral-Leite, M. \& Gomes, P. 1203(28); 1204(7); 1206(26); 1207(26); 1208(26); 1209(26); Viana, A. et al. 252(8); 327(8). 